Field Trip Guide to Serpentinite, Silica-Carbonate Alteration, and Related Hydrothermal Activity in the Clear Lake Region, California

Fraser Goff

George Guthrie 


\section{DISCLAIMER}

This report was prepared as an account of work sponsored by an agency of the United States Government. Neither the United States Government nor any agency thereof, nor any of their employees, make any warranty, express or implied, or assumes any legal liability or responsibility for the accuracy, completeness, or usefulness of any information, apparatus, product, or process disclosed, or represents that its use would not infringe privately owned rights. Reference herein to any specific commercial product, process, or service by trade name, trademark, manufacturer, or otherwise does not necessarily constitute or imply its endorsement, recommendation, or favoring by the United States Government or any agency thereof. The views and opinions of authors expressed herein do not necessarily state or reflect those of the United States Government or any agency thereof. 


\section{DISCLAIMER}

Portions of this document may be illegible in electronic image products. Images are produced from the best available original document. 


\section{CONTENTS}

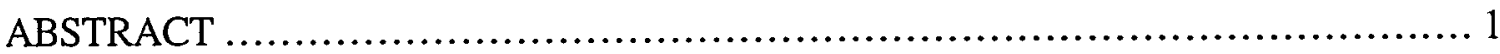

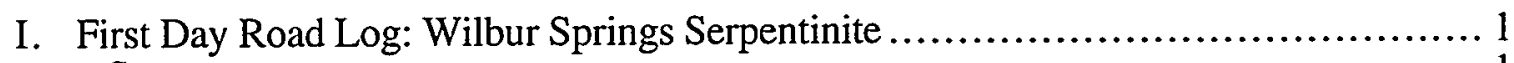

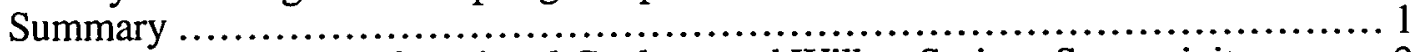

STOP 1-1: Overview of Regional Geology and Wilbur Springs Serpentinite......... 3

STOP 1-2: Wilbur Springs Serpentinite and Complexion Spring. .................. 5

STOP 1-3: Allen Springs, Silica-Carbonate Rock, and Bartlett Springs Fault Zone.. 9

STOP 1-4: Wilbur Springs Serpentinite and Unnamed Fault. ........................ 9

STOP 1-5: Serpentine Breccia at Turkey Run Mine.............................. 11

II. Second Day Road Log: McLaughlin Mine Area, Faulted Serpentinites South

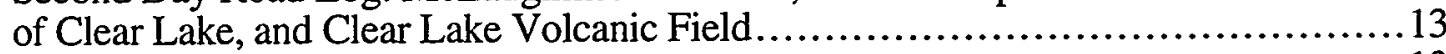

Summary ..................................................................... 13

STOP 2-1a: McLaughlin Gold Mine. ........................................ 13

STOP 2-1b: Knoxville Mine and Silica-Carbonate Rock. ........................ 15

STOP 2-1c: Reed Mine and Silica-Carbonate Rock. .............................. 15

STOP 2-2: Howard Hot Springs. ................................................ 17

STOP 2-3: Serpentinite along Collayomi Fault Zone............................. 19

STOP 2-4: Little Borax Lake Maar and Buckingham Peak......................... 19

III. Third Day Road Log: Southeast Geysers Geothermal Field and Veined

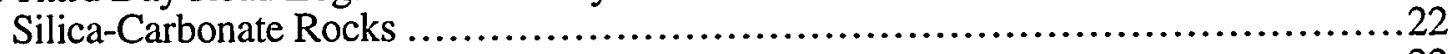

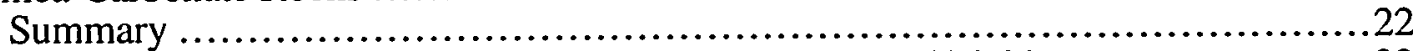

STOP 3-1a: Overview of Southeast Geysers Geothermal Field. ..................22

STOP 3-1b: Faulted and Veined Silica-Carbonate Rock near 956-1 Injection Well. .24

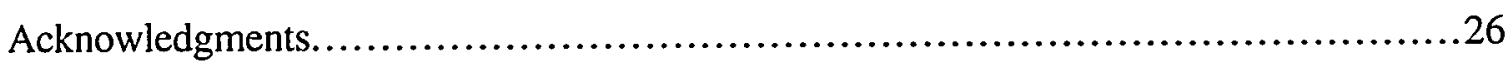

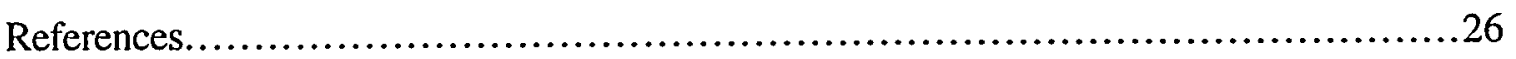




\title{
FIELD TRIP GUIDE TO SERPENTINITE, SILICA-CARBONATE ALTERATION, AND RELATED HYDROTHERMAL ACTIVITY IN THE CLEAR LAKE REGION, CALIFORNIA
}

\author{
by \\ Fraser Goff and George Guthrie
}

\begin{abstract}
This guide is designed to familiarize scientists with the geology, structure, alteration, and fluids typical of California serpentinites for purposes of carbon dioxide sequestration (Lackner et al., 1995). Goff et al. (1997) and Goff and Lackner (1998) describe the geology and geochemistry of some of the serpentinites from this area. Mechanisms of silica-carbonate alteration were outlined by Barnes et al. (1973). Donnelly-Nolan et al. (1993) most recently reviewed relations between regional hydrothermal alteration and Quaternary volcanic activity. Stanley et al. (1998) summarized geophysical characteristics of the region.
\end{abstract}

\section{First Day Road Log: Wilbur Springs Serpentinite}

Summary-During the first day you will examine the geology and structure of the large, flat-lying Wilbur Springs serpentinite, observe mineral springs that issue from serpentinite, and look at faulted silica-carbonate rock.

Approximate mileage is given except where noted by tenths or hundredths of miles. Leave Oakland airport; turn north on I-880, go roughly 5 miles to junction with I-80, and continue north 45 miles on I-80 toward Sacramento (Figure 1). Just after passing Vacaville, take the I-505 exit and go north toward I-5 and Redding. In about 30 miles, I505 joins I-5. Continue north another 20 miles on I-5 to Williams.

Turn left (west) on Highway 20 towards Clearlake. You will be driving from the flat Central Valley toward the east edge of the California Coast Ranges (Cortina Ridge). Go about 19 miles to Bear Creek Road. Turn right (northwest) on Bear Creek Road. After 3.85 miles you will reach the junction with Wilbur Springs Road that crosses Bear Creek on an old bridge. Do not cross the bridge. Continue north on Bear Creek Road. Follow Bear Creek, passing through shale-rich outcrops of the Jurassic Knoxville Formation, and then enter the long linear Bear Valley. Go about 15 miles to the junction with Bartlett Springs Road (Figure 2). Turn left at the junction and park at a convenient location. 


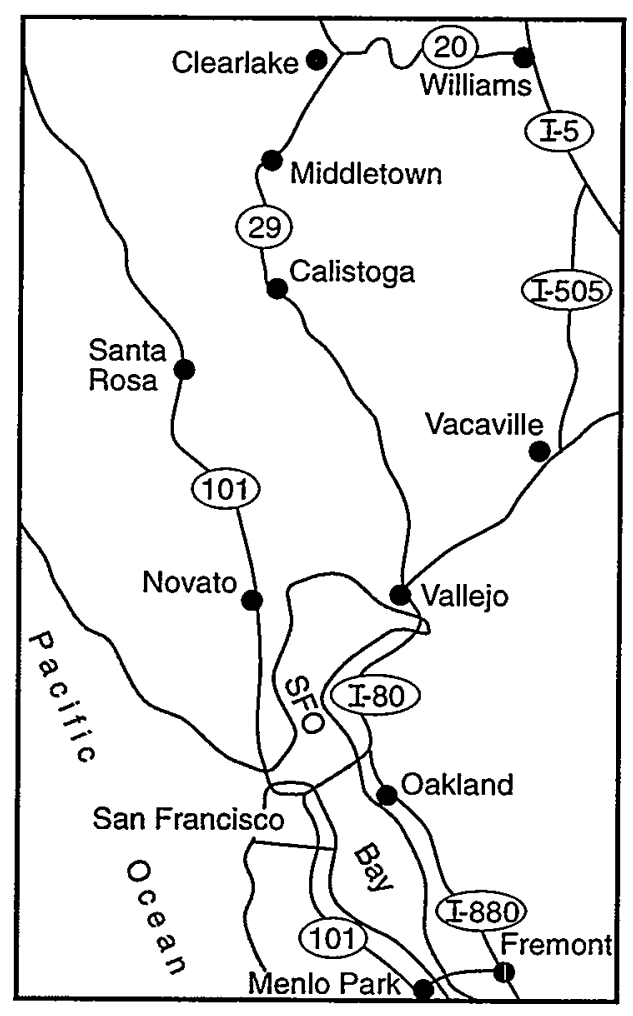

Figure 1. Road map of San Francisco Bay Area showing route to Williams, California.

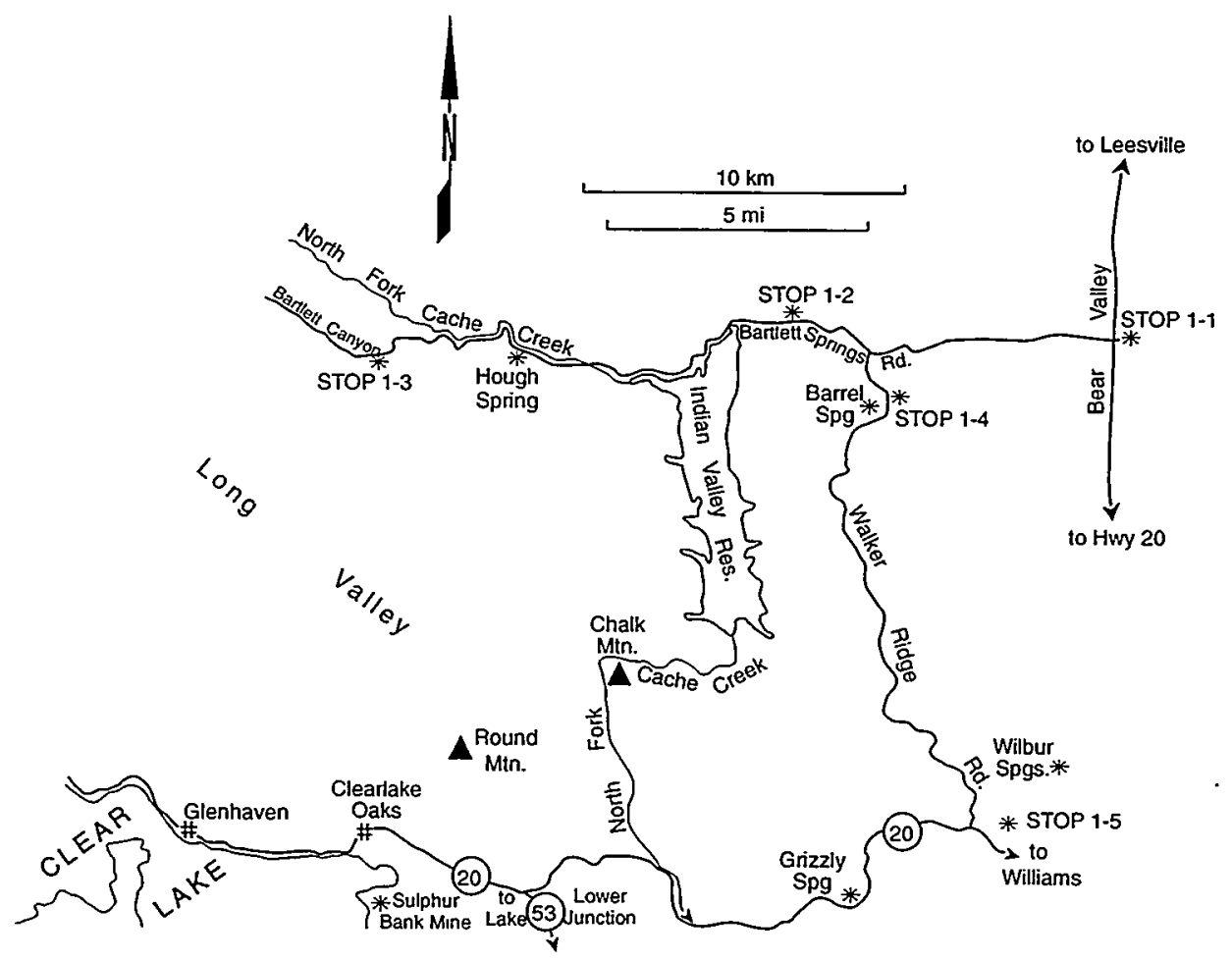

Figure 2. Route map of Day 1. 
STOP 1-1: Overview of Regional Geology and Wilbur Springs Serpentinite.We are standing in Bear Valley that formed in a zone of erosion between ridges of bedded, eastward-dipping sandstone and shale to the east and a thick slab of serpentinite forming Walker Ridge to the west (Rich, 1971). We are located about $5 \mathrm{~km}$ east of point $\mathrm{C}$ on Figure 3. Major points of this stop:

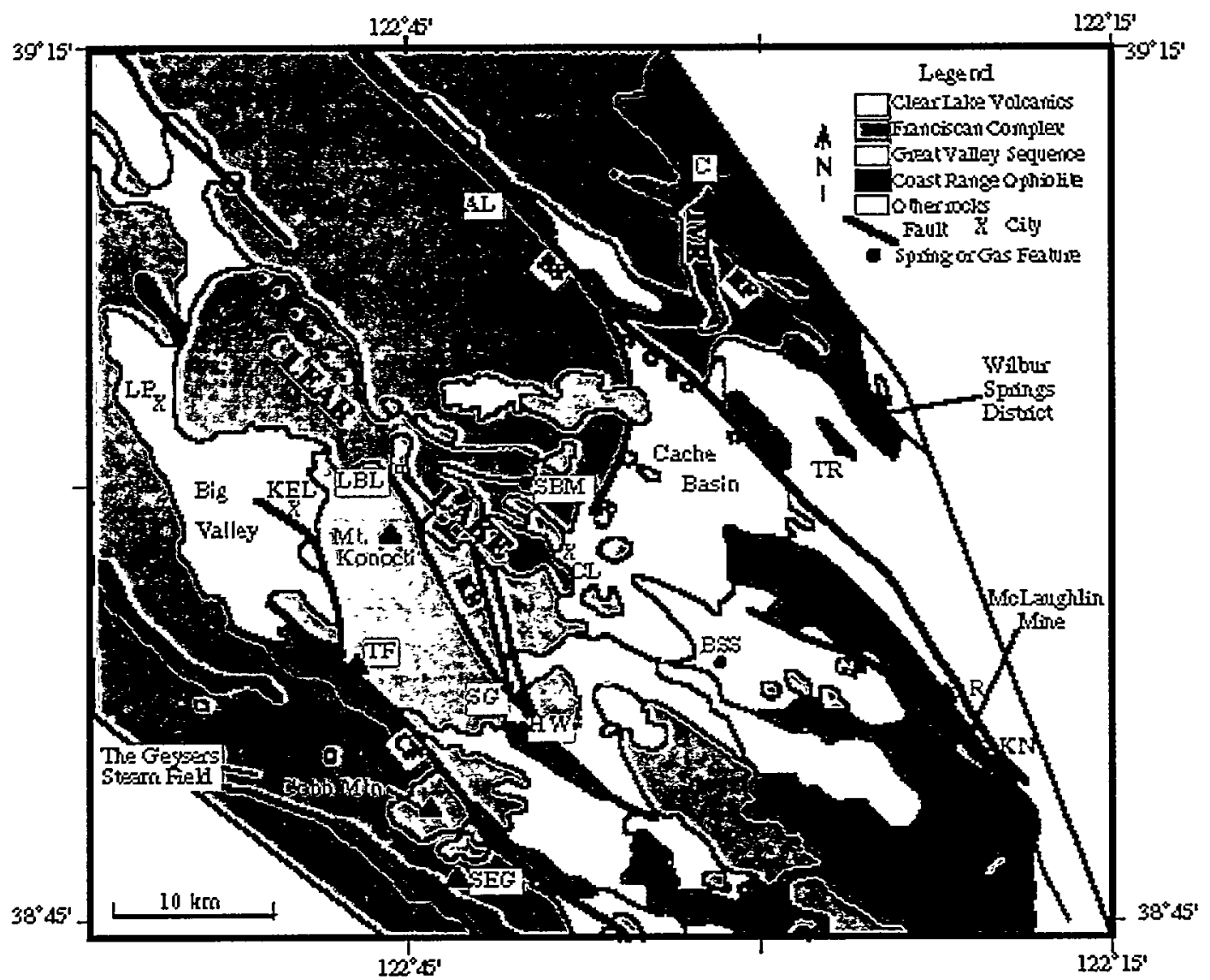

Figure 3. Generalized geologic map of the Clear Lake region, California, showing major formations, faults, and locations or areas to be visited during the field trip (modified from Goff and Janik, 1993). Major faults: BS = Bartlett Springs fault zone; $C F=$ Collayomi fault zone; $C S=$ Cross Spring fault zone; $\mathrm{GP}=$ Grizzly Peak fault zone; $\mathrm{KB}=$ Konocti Bay fault zone; $\mathrm{RF}=$ Resort fault zone. $\mathrm{LP}=$ city of Lakeport; $\mathrm{SBM}=$ Sulphur Bank Mine. Day 1: $\mathrm{AL}=$ Allen Springs; $C=$ Complexion Spring; $C L=$ City of Clearlake; IVR = Indian Valley Reservoir; TR = Turkey Run Mine. Day 2: BSS = Baker Soda Spring; $\mathrm{HW}=$ Howard Hot Springs; KEL = Kelseyville; $\mathrm{KN}=$ Knoxville Mine; LBL $=$ Little Borax Lake; $\mathrm{R}=$ Reed Mine; $\mathrm{SG}=$ Seigler Hot Springs; TF = thrust fault along Collayomi fault zone. Day 3: SEG = Southeast Geysers area.

1. Two great geologic formations comprise the California Coast Ranges; the Great Valley sequence (GVS) composed of well-bedded sandstone and shale; and the Franciscan Complex (FC) composed mostly of deformed graywacke and shale (Bailey et al., 1964).

2. The basal part of the GVS includes oceanic crust of the Coast Range ophiolite. Ophiolite (Coleman, 1977) is the name given to a specific rock association of uplifted 
oceanic crust: from bottom to top, it consists of mantle ultramafic rocks, mafic intrusive rocks, lava flows, pillow basalt, chert, and shale (the shale unit in the GVS is named the Knoxville Formation).

3. The ultramafic layer forming Walker Ridge is approximately $95 \%$ serpentinite, is several hundred meters thick, is about $50 \mathrm{~km}$ long, and averages $4 \mathrm{~km}$ wide.

4. The GVS and basal ophiolite were uplifted and thrust over FC in late Cretaceous and early Tertiary time at about $60 \mathrm{Ma}$ (Figure 4). Because the uplift dips to the east, the basal serpentinite forms a linear north-trending slab on the west edge of the uplift.

A

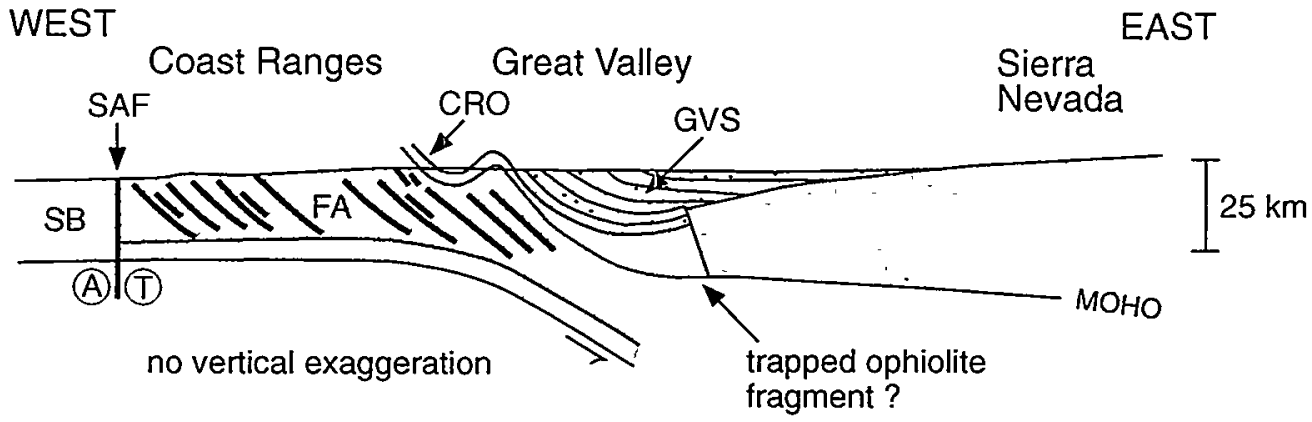

B WEST

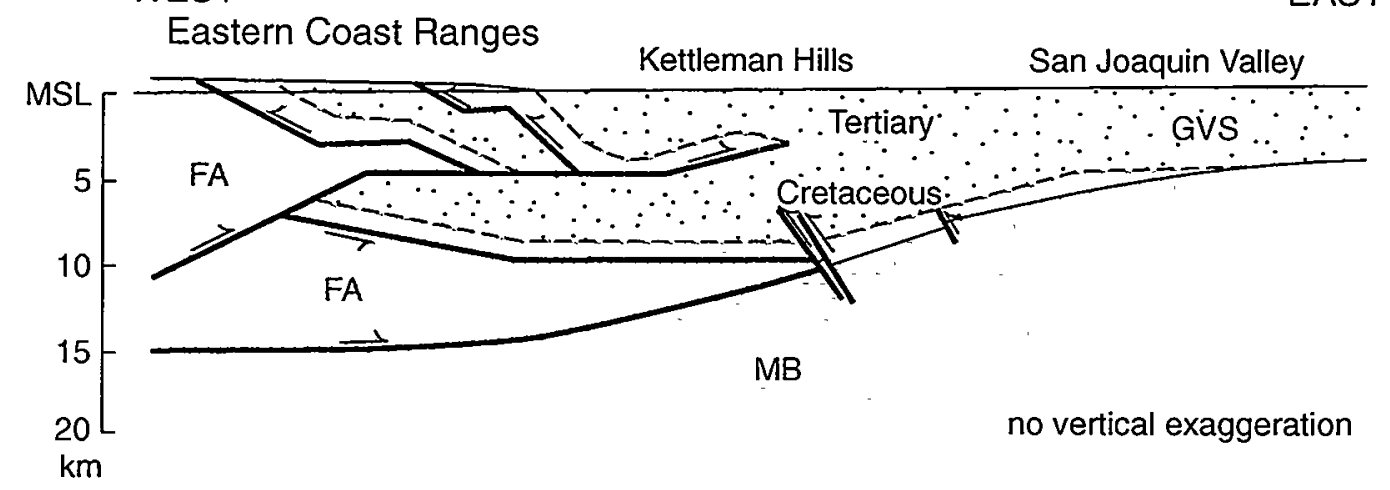

EAST

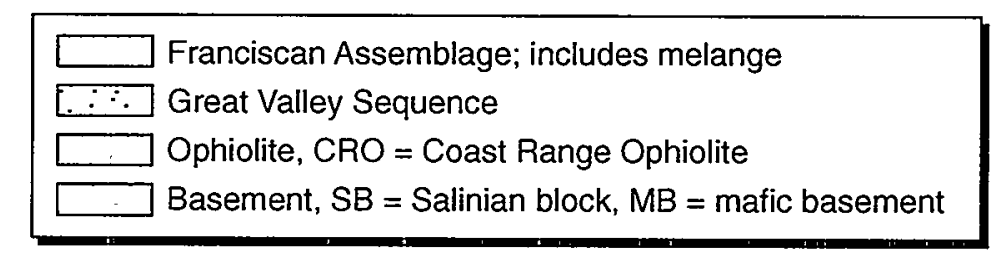

Figure 4. Models for the crustal structure of western California: A. Simple eastplunging subduction model of Dickenson and Seely (1979). B. More complicated tectonic wedging model of Unruh et al. (1991). Benz et al. (1992) summarized the tectonics of this region. SAF = San Andreas Fault.

5. Serpentinites host a unique flora because their soils contain low potassium and phosphorus. In this region, the flora consist of cypress, gray pine, manzanita, live oak, and other shrubs. Serpentinite is not usually a good host rock for grasses. 
6. As you observe the surroundings, consider the feasibility and environmental impact of a huge open-pit serpentine mine in this region.

Continue west on Bartlett Springs Road. Within 2 miles, the road climbs from the valley floor up Walker Ridge past subdued slopes of Knoxville Formation shale into massive Wilbur Springs serpentinite. Structurally, the serpentinite underlies the shale. In about 1.5 miles, you will reach the junction with Walker Ridge Road at the crest of a broad ridge. Continue west on Bartlett Springs Road. Cross a small bridge at 2.1 miles and continue another 0.25 mile past Complexion Spring Canyon. Park in the turnout on the right side of the road.

STOP 1-2: Wilbur Springs Serpentinite and Complexion Spring. [CAUTION: this is rattlesnake country!] Walk down to the stream and find a good point to cross. Walk upstream on the north bank about $100 \mathrm{~m}$ to Complexion Springs Canyon. Walk about $200 \mathrm{~m}$ along a poorly defined path on the west bank of the stream in Complexion Springs Canyon. Cross the stream above the small waterfall. Note cemented serpentine gravel in the streambed. Contour uphill along the east bank about $15 \mathrm{~m}$ above the stream. Enter the first major gully to the east. Climb $25 \mathrm{~m}$ uphill. Complexion Spring issues as a seep from a small hole ( $0.3 \mathrm{~m}$ wide by $0.2 \mathrm{~m}$ high) in the side of a serpentine hill on the south bank of the gully near the base of two cypress trees.

You are standing in the "middle" of the north-trending Wilbur Springs serpentinite (Figure 3; McLaughlin et al., 1989), which at this location is relatively massive and was originally a harzburgite (Figure 5; orthopyroxene $\geq 10 \%, \leq 90 \%$ forsteritic olivine, and minor spinel). The rocks here are fairly typical of those exposed throughout most of the body. On broken surfaces, serpentinized relicts of the orthopyroxene crystals (bastite) form little flat plates. Some hydromagnesite alteration can be seen in outcrops along the gullies typically forming white millimeter-sized nodules. Analysis UM96-7 (Table 1) was obtained from a sample of serpentinite atop the ridge to the northwest.

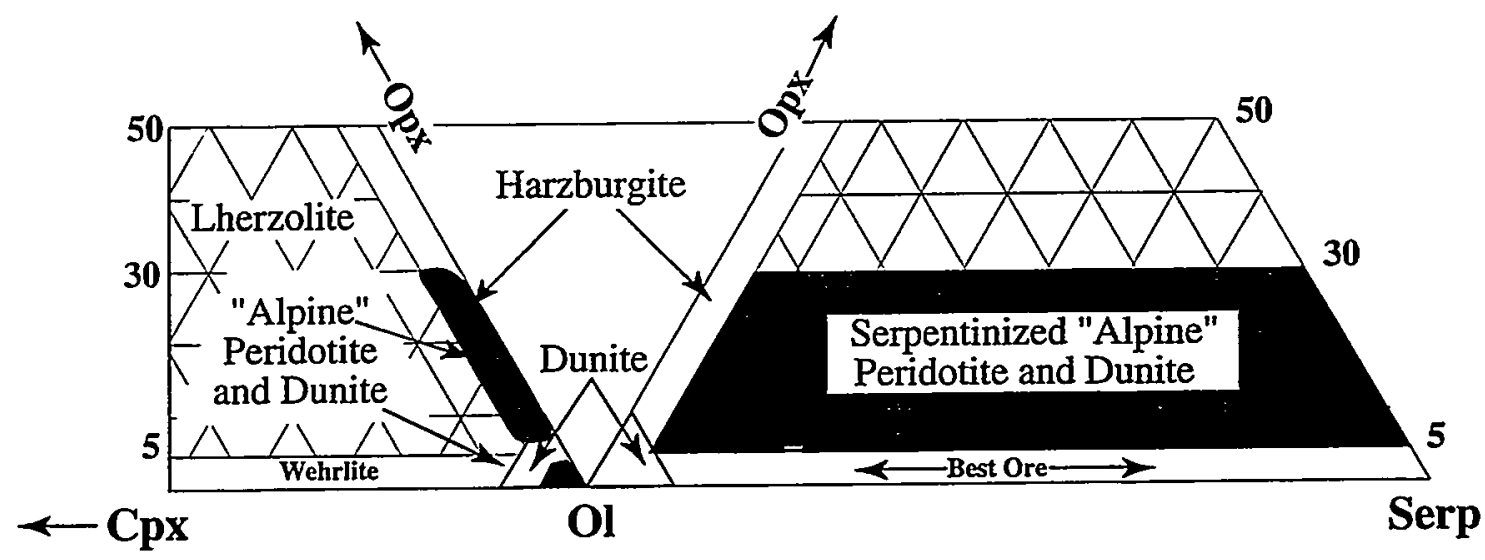

Figure 5. Diagram showing lower right corner of the orthopyroxene-clinopyroxeneolivine (Opx-Cpx-Ol) ternary and the lower half of the orthopyroxene-olivineserpentine (Opx-Ol-Serp) ternary (modal-\%). Numbers around the perimeter of the diagram are the percent orthopyroxene (Goff and Lackner, 1998). 
Table 1: Chemical composition of rocks from the Wilbur Springs ultramafic mass and other units in the Clear Lake region, California.

\begin{tabular}{|c|c|c|c|c|c|c|c|c|c|}
\hline \multirow{3}{*}{$\begin{array}{l}\text { Sample } \\
\text { Type }\end{array}$} & \multicolumn{6}{|c|}{ Wilbur Springs Serpentinite ${ }^{a}$} & \multicolumn{2}{|c|}{ Franciscan Complex } & \multirow{2}{*}{$\frac{\text { CL Volc. }}{\text { F91-7 }}$} \\
\hline & UM96-1 ${ }^{b}$ & UM96-3 & UM96-7 & UM96-10 & UM96-14 & $\mathrm{UMWS}-\mathrm{AVE}^{\mathrm{g}}$ & F $92-35^{h}$ & F92-36 & \\
\hline & Serpentinite & Serpentinite & Serpentine & Serpentinite & Serpentinite & Serpentinite & Greenstone & Graywacke & Dacite \\
\hline \multicolumn{10}{|c|}{ Major Oxides (wt \%) } \\
\hline $\mathrm{SiO}_{2}$ & 40.79 & 39.75 & 41.85 & 40.66 & 39.47 & $40.6 \pm 1.2$ & 48.86 & 72.25 & 64.93 \\
\hline $\mathrm{TiO}_{2}$ & 0.031 & 0.080 & 0.000 & 0.048 & 0.078 & $0.040 \pm 0.02$ & 1.23 & 0.587 & 0.77 \\
\hline $\mathrm{Al}_{2} \mathrm{O}_{3}$ & 1.57 & 2.28 & 0.50 & 2.56 & 3.20 & $1.99 \pm 0.40$ & 15.41 & 11.50 & 15.65 \\
\hline $\mathrm{Fe}_{2} \mathrm{O}_{3}$ & 6.10 & 6.80 & 6.58 & 5.65 & 6.27 & $5.06 \pm 1.3$ & 10.10 & 4.77 & 4.20 \\
\hline $\mathrm{FeO}$ & 1.90 & 1.38 & 1.02 & 2.39 & 2.54 & $2.94 \pm 1.0$ & - & $\ldots$ & $-\ldots$ \\
\hline $\mathrm{MnO}$ & 0.143 & 0.147 & 0.126 & 0.120 & 0.147 & $0.138 \pm 0.15$ & 0.16 & 0.07 & 0.07 \\
\hline $\mathrm{MgO}$ & 36.32 & 34.61 & 37.13 & 35.79 & 35.41 & $36.2 \pm 1.1$ & 6.01 & 2.34 & 3.40 \\
\hline $\mathrm{CaO}$ & 0.00 & 0.17 & 0.27 & 0.00 & 0.00 & $0.42 \pm 0.1$ & 12.83 & 1.60 & 5.06 \\
\hline $\mathrm{Na}_{2} \mathrm{O}$ & 0.00 & 0.00 & 0.00 & 0.00 & 0.00 & 0.00 & 2.99 & 2.85 & 3.60 \\
\hline $\mathrm{K}_{2} \mathrm{O}$ & 0.00 & 0.00 & 0.00 & 0.00 & 0.00 & 0.00 & 0.15 & 1.64 & 2.32 \\
\hline $\mathrm{P}_{2} \mathrm{O}_{5}$ & $<0.005$ & $<0.005$ & $<0.005$ & $<0.005$ & $<0.005$ & $<0.005$ & 0.129 & 0.098 & 0.18 \\
\hline $\mathrm{NiO}$ & 0.32 & 0.34 & 0.34 & 0.32 & 0.29 & 0.32 & 0.01 & 0.01 & -- \\
\hline $\mathrm{Cr}_{2} \mathrm{O}_{3}$ & 0.42 & 0.45 & 0.47 & 0.41 & 0.45 & 0.40 & 0.02 & 0.03 & 0.01 \\
\hline LOI & 13.28 & 13.76 & 12.82 & 12.81 & 13.26 & $12.6 \pm 1.1$ & 2.02 & 1.95 & 0.35 \\
\hline TOTAL & 100.9 & 99.77 & 101.1 & 100.8 & 101.2 & 100.7 & 99.92 & 99.70 & 100.5 \\
\hline $\begin{array}{l}{\mathrm{MgO} / \mathrm{SiO}_{2}}_{\%} \text { Serp. }\end{array}$ & $\begin{array}{l}0.890 \\
100\end{array}$ & $100^{0.871}$ & $\begin{array}{l}0.887 \\
75\end{array}$ & $\begin{array}{l}0.880 \\
80^{0}\end{array}$ & $\begin{array}{l}0.897 \\
85\end{array}$ & $\begin{array}{r}0.892 \\
05+5\end{array}$ & 0.123 & 0.032 & 0.052 \\
\hline (1) & & & & & & & 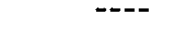 & $\cdots$ & \\
\hline
\end{tabular}

$=$ Analyses previously published in Goff et al. (1997); LOI = loss on ignition.

$b=$ East margin of serpentinite on Bartlett Springs Road.

$c=$ Radio Facility north of the junction of Bartlett Springs and Walker Ridge Roads.

$\mathrm{d}=$ Summit of ridge NW of Complexion Spring.

${ }^{c}=$ West margin of serpentinite, NW of Indian Valley Reservoir.

$\mathrm{f}=$ Crest of hill, Walker Ridge Road about $1.6 \mathrm{~km} \mathrm{~S}$ of junction with Bartlett Springs Road (Stop 1-4).

$\mathfrak{g}=$ Average of 15 samples with standard deviation $(1 \sigma)$ from Goff et al. (1997).

$"=$ Greenstone (metabasalt) from The Geysers; all $\mathrm{Fe}$ as $\mathrm{Fe}_{2} \mathrm{O}_{3}$.

$=$ Graywacke from The Geysers; all $\mathrm{Fe}$ as $\mathrm{Fe}_{2} \mathrm{O}_{3}$

= Dacite lava from Konocti Bay, Soda Bay Road; all $\mathrm{Fe}$ as $\mathrm{Fe}_{2} \mathrm{O}_{3}$. 
Complexion Spring water slowly flows into a shallow, milky-white pool with a film of salt on the surface (Figure 6). Brucite $\left(\mathrm{Mg}(\mathrm{OH})_{2}\right)$ deposition apparently causes the milky appearance. At one time, Complexion Spring water was used as a nasal douche and as a rinse for sores (Waring, 1915). The water has a bitter salty taste with overtones of ammonia. The water is extremely alkaline (roughly $\mathrm{pH} 11$ ) and has the approximate salinity of seawater. Mineral waters in this region have $\mathrm{Br} / \mathrm{Cl}$ identical to seawater (Table 2). Complexion Spring is one of the most unusual natural fluids discharging from serpentine (Barnes et al., 1972).

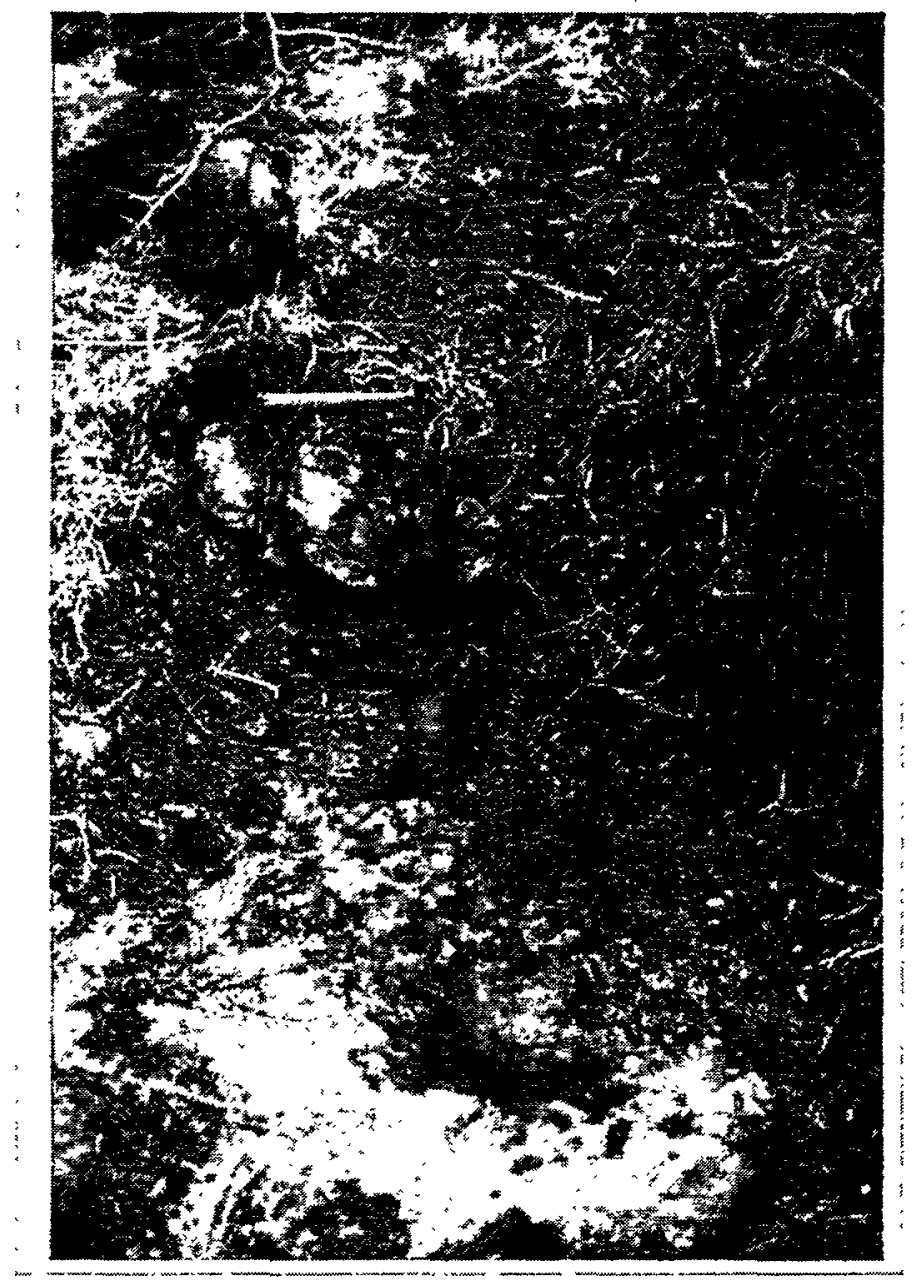

Figure 6. View looking south of Complexion Spring, which seeps from massive serpentinized harzburgite. Although it is the most saline spring in the Clear Lake region, Complexion Spring ranges from $9^{\circ} \mathrm{C}$ to $18^{\circ} \mathrm{C}$ and varies in salinity depending on the time of year and rainfall. Complexion Spring has been cited as an example of a "serpentinizing" fluid (Barnes et al., 1972).

Continue west on Bartlett Springs Road. At 0.75 mile you enter upper Little Indian Valley, and in 2.0 miles you pass from serpentinite into sandstone/shale of the FC. In another 0.5 mile you enter the North Fork of Cache Creek. Go 3.6 miles more to the ruins of Hough Springs (on the left). Continue northwest another 4.25 miles to Allen Springs (subdued ruins on the right) and park 0.1 mile beyond the ruins in a large turnout on the right. 
Table 2: Chemical composition of selected spring waters from the Clear Lake region, California."

\begin{tabular}{|c|c|c|c|c|c|c|c|c|c|c|}
\hline Name & Complexion & Allen & Barrel & Turkey Run & Baker Soda & Howard & Seigler & Big Soda & L. Borax & Anderson \\
\hline Sample & CL91-15 & CL92-37 & CL91-14 & CL93-47 & CL91-5 & CL91-26 & Spg 2 & CL91-2 & CL93-72 & CL91-19 \\
\hline Type & C & TM & M & C & $\mathrm{C}$ & TM & $\mathrm{TM}$ & $\mathrm{TM}$ & $\mathrm{M}$ & $\mathrm{AS}$ \\
\hline Rocks $^{c}$ & $S p(G V)$ & Sp-F-GV & Sp & Sp-GV & Sp-GV & $S p-G V(F)$ & $\mathrm{Sp}-\mathrm{GV}(\mathrm{F})$ & $\mathrm{CLV}(\mathrm{Sp})$ & $\mathrm{CLV}(\mathrm{Sp})$ & $\mathrm{F}$ \\
\hline Temp $\left({ }^{\circ} \mathrm{C}\right)$ & 8.9 & 17.0 & 10.8 & 29.0 & 21.3 & 46.3 & 52 & 31.3 & 11 & 49.4 \\
\hline pH (field) & 11.5 & 6.0 & 6.8 & 6.5 & 6.8 & 6.58 & 6.22 & 5.8 & 8.8 & 5.5 \\
\hline $\mathrm{SiO}_{2}$ & 15 & 97 & 50 & 83 & 88 & 156 & 170 & 133 & 7.57 & 85 \\
\hline $\mathrm{Na}$ & 11845 & 297 & 7.8 & 932 & 2600 & 254 & 162 & 95 & 360 & 39 \\
\hline $\mathrm{K}$ & 335 & 8.37 & $<0.1$ & 29.8 & 207 & 21.7 & 20 & 11.5 & 131 & 9.5 \\
\hline $\mathrm{Li}$ & $<0.1$ & 2.37 & $<0.01$ & 1.93 & 6.25 & 1.30 & --- & 0.45 & 0.16 & 0.18 \\
\hline $\mathrm{NH}_{4}$ & 112 & 11.8 & 0.07 & 22.7 & 138 & 15.0 & 11.8 & $<0.05$ & 1.45 & 18.9 \\
\hline $\mathrm{Ca}$ & 3.7 & 152 & 11.8 & 62.2 & 92.6 & 31.6 & 30 & 79.8 & 9.18 & 157 \\
\hline $\mathrm{Mg}$ & 22.9 & 420 & 83.8 & 936 & 279 & 297 & 238 & 110 & 134 & 52.4 \\
\hline $\mathrm{Sr}$ & 0.50 & 1.89 & 0.10 & 3.00 & 2.00 & 1.00 &.-- & 0.58 & 0.43 & 1.19 \\
\hline $\mathrm{Fe}$ & $<0.1$ & 13.1 & 0.03 & 0.12 & $<0.05$ & 0.12 & 0.22 & 17.8 & 0.09 & 20.0 \\
\hline $\mathrm{Mn}$ & $<0.1$ & 0.35 & $<0.01$ & 0.26 & 0.25 & 0.06 & 0.02 & 0.52 & 0.20 & 9.52 \\
\hline Al & $0.016^{\mathrm{d}}$ & $<0.2^{\mathrm{e}}$ & $<0.1^{\mathrm{e}}$ & $<0.1^{\mathrm{e}}$ & $0.027^{\mathrm{d}}$ & $0.008^{\mathrm{d}}$ & $0.66^{\mathrm{e}}$ & $0.026^{\mathrm{d}}$ & $0.09^{\mathrm{e}}$ & $<0.1^{\mathrm{e}}$ \\
\hline$F$ & 0.14 & $<0.05$ & 0.03 & 0.20 & 0.52 & $<0.02$ & $<0.1$ & 0.32 & 0.42 & 0.35 \\
\hline $\mathrm{Cl}$ & 17260 & 470 & 9.5 & 110 & 2990 & 457 & 272 & 56.8 & 53.3 & 2.1 \\
\hline $\mathrm{Br}$ & 56.2 & 1.64 & $<0.02$ & 3.26 & 11.1 & 2.35 & 2 & 0.27 & 0.20 & $<0.02$ \\
\hline $\mathrm{HCO}_{3}$ & 0 & 1841 & 370 & 2330 & 4650 & 1680 & 1258 & 1040 & 1230 & 203 \\
\hline $\mathrm{CO}_{3}$ & 220 & 422 & 60 & 0 & 0 & 0 & 0.2 & 0 & 220 & 0 \\
\hline $\mathrm{SO}_{4}$ & 48.5 & 2.09 & 4.1 & 2550 & 0.25 & 0.1 & 6.3 & 0.2 & 19.8 & 619 \\
\hline F & 17 & 45.9 & $<0.02$ & 39.6 & 171 & 37.4 & 19 & 12.3 & 48.1 & $<0.02$ \\
\hline As & $<0.1$ & 0.5 & $<0.05$ & $<0.05$ & 0.7 & $<0.1$ & $-\cdots$ & $<0.1$ & 0.031 & $<0.05$ \\
\hline TDS & 30240 & 3790 & 597 & 8120 & 11250 & 2960 & 2190 & 1560 & 2220 & 1220 \\
\hline Bal (\%) & 4.8 & -4.2 & -7.0 & -1.6 & -8.3 & -8.5 & 1.9 & -4.9 & -6.2 & 1.2 \\
\hline
\end{tabular}

" Values in ppm unless otherwise noted; data from Goff et al. (1992 and unpublished) except Seigler (Barnes et al., 1973).

b $\mathrm{AS}=$ acid-sulfate; $\mathrm{C}=$ connate; $\mathrm{M}=$ meteoric; $\mathrm{TM}=$ thermal meteoric (see Goff et al., 1992 for explanation of definitions).

${ }^{\circ} \mathrm{CLV}=$ Clear Lake Volcanics; F = Franciscan Complex; GV = Great Valley sequence; $\mathrm{Sp}=$ serpentinite; parentheses = formation or unit at ${ }^{d}$ Monomeric aluminum species.

Total aluminum. 
STOP 1-3: Allen Springs, Silica-Carbonate Rock, and Bartlett Springs Fault Zone. Silica-carbonate (SC) rock is a name given to hydrothermally altered serpentine that has been converted to silica (opal and quartz) plus carbonate (magnesite, calcite, and/or dolomite). The outcrop adjacent to the turnout displays an outstanding contact between SC rock/serpentinite on the left and sheared Knoxville Formation shale on the right. This is the main trace of the Bartlett Springs fault zone, a right-lateral, strike-slip fault that is part of the greater San Andreas transform zone (Figure 3). The trend of the fault is northwest. The shale is a thin wedge of GVS rocks caught up in the fault zone, and the shale dips steeply to the northeast. This thin belt of serpentinite and GVS parallels the fault zone for many kilometers.

Cross the road and descend the embankment. Several carbonated springs $\left(17^{\circ} \mathrm{C}\right.$ to $\left.20^{\circ} \mathrm{C}\right)$ issue from brecciated SC rock in the Bartlett Springs fault zone. During high water, all springs are flooded. Rocks around the orifices and in discharge channels are stained an intense orange color from iron oxide deposition. A weak, but constant flow of gas bubbles from most of the springs. The water tastes rich in iron and soda and has a faint salty sweet flavor from chloride and magnesium (Table 2). The area smells a little of $\mathrm{H}_{2} \mathrm{~S}$ but the gas consists mostly of $\mathrm{CO}_{2}$ and air components (Table 3). Various types of carbonated waters issue from serpentinite and silica-carbonate rock in fault zones throughout the Clear Lake region (Barnes et al., 1973). They typically have high $\mathrm{Mg} / \mathrm{Ca}$ (Table 2). Carbon dioxide in the Clear Lake region has relatively depleted carbon-13 values (mostly less than -10\%o $\delta^{13} \mathrm{C}^{-} \mathrm{CO}_{2}$ ) indicating mostly organic sources (Bergfeld et al., in press).

Turn around. Retrace route 13.5 miles back to Walker Ridge Road. Turn right (south), go about 1 mile, and park just beyond of crest of the small hill.

STOP 1-4: Wilbur Springs Serpentinite and Unnamed Fault. The pretty green serpentine at this location is the source of sample UM96-14 (Table 1). About $40 \mathrm{~kg}$ of this rock was recently powdered and distributed for several $\mathrm{CO}_{2}$ sequestration studies (Los Alamos National Laboratory bulk sample UM98-1). The mineralogy consists of nearly pure serpentine (mostly lizardite) with minor spinel; minor chlorite is found in the veinlets (XRD). The outcrop consists of larger blocks of massive serpentine surrounded by smaller and smaller fragments of sheared, platy rock. This appearance of the serpentinite is more or less similar for many kilometers south.

Walk about $50 \mathrm{~m}$ north along the road. A WNW-trending fault is exposed along the west road cut juxtaposing highly sheared serpentinite (south) against broken, contorted chert (Figure 7). This type of chert forms by slow accumulation of diatom skeletons in deepwater marine environments and tends to be manganese rich. Presumably, the chert is a fragment of the upper part of the Coast Range ophiolite, but because geologic structure in this region is complicated, it is not clear if the chert should be assigned to the FC or the GVS. Nearby is Barrel Spring that discharges cold meteoric water with the high $\mathrm{Mg} / \mathrm{Ca}$ ratio common to serpentinite-derived fluids (Table 2). 
Table 3: Gas composition of selected spring and vent discharges in the Clear Lake region, California. ${ }^{\mathrm{a}}$

\begin{tabular}{|c|c|c|c|c|c|c|c|c|c|c|}
\hline Name & Allen & Wilbur & Baker Soda & Howard & Seigler & Kelseyville & Big Soda & Horseshoe & Anderson & CPAb-1 $1^{b}$ \\
\hline Sample & CL92-37 & CL95-9 & CL91-5 & CL91-26 & Spg 2 & CL95-1 & CL92-42 & CL95-14 & CL95-2 & G87-91 \\
\hline Type $^{c}$ & S & $\mathrm{G}$ & S & S & $\mathrm{S}$ & $\mathrm{OF}$ & S & $\mathrm{S}$ & $\mathrm{G}$ & $\mathrm{G}$ \\
\hline Rocks $^{\mathrm{d}}$ & Sp-F-GV & $\mathrm{Sp}-\mathrm{GV}$ & $\mathrm{Sp}-\mathrm{GV}$ & $\mathrm{Sp}-\mathrm{GV}(\mathrm{F})$ & Sp-GV & $A(F-S p)$ & $\operatorname{CLV}(\mathrm{Sp})$ & $\mathrm{CLV}(\mathrm{Sp})$ & $\mathrm{F}$ & F-Sp \\
\hline $\operatorname{Temp}\left({ }^{\circ} \mathrm{C}\right)$ & 17 & 56.5 & 21.3 & 46.3 & 52 & 13.7 & 31 & 40 & 76.6 & $\geq 240$ \\
\hline $\mathrm{CO}_{2}$ & 84.3 & 91.1 & 98.8 & 99.7 & 92.1 & 64.7 & 99.6 & 93.5 & 90.5 & 48.5 \\
\hline $\mathrm{H}_{2} \mathrm{~S}$ & 0.35 & 3.14 & 0.000 & 0.000 & ---- & 0.021 & 0.0008 & 0.0043 & 2.91 & 7.68 \\
\hline $\mathrm{CH}_{4}$ & 0.0302 & 4.88 & 0.714 & 0.058 & 3.1 & 31.1 & 0.296 & 2.28 & 3.85 & 5.62 \\
\hline $\mathrm{H}_{2}$ & nd & 0.0011 & 0.0000 & 0.0011 & ---- & 0.0163 & nd & 0.0034 & 0.0289 & 28.2 \\
\hline $\mathrm{NH}_{3}$ & 0.0026 & 0.0019 & 0.0002 & 0.0001 & $-\cdots$ & 0.0075 & 0.00003 & 0.00094 & 0.00177 & 7.35 \\
\hline $\mathrm{N}_{2}$ & 12.1 & 0.838 & 0.392 & 0.204 & 2.3 & 3.93 & 0.0922 & 2.90 & 2.55 & 2.46 \\
\hline $\mathrm{O}_{2}^{2}$ & 3.54 & 0.0033 & 0.110 & 0.0778 & $1.2^{\mathrm{e}}$ & 0.165 & 0.038 & 1.24 & 0.000 & 0.038 \\
\hline $\mathrm{Ar}$ & 0.158 & 0.0231 & 0.0062 & 0.0049 & $\cdots$ & 0.0065 & 0.002 & 0.0627 & 0.0424 & 0.023 \\
\hline $\mathrm{He}$ & 0.00058 & 0.00033 & 0.0022 & $<0.0001$ & ---- & 0.00277 & $<0.0001$ & 0.00098 & $<0.0001$ & 0.005 \\
\hline TOTAL & 100.5 & 99.99 & 100.0 & 100.0 & 98.7 & 99.95 & 100.0 & 99.99 & 99.88 & 99.88 \\
\hline
\end{tabular}

"Values in mol \% dry gas; nd = not detected; data from Goff and Janik (1993) and Janik and Goff (in prep.) except Seigler (Barnes et al., 1973).

${ }^{\mathrm{b}} \mathrm{Cal}$ Pine Abel-1 production well, Southeast Geysers geothermal field.

${ }^{c} \mathrm{G}=$ geothermal; $\mathrm{OF}=$ oil field; $\mathrm{S}=$ soda.

${ }^{\mathrm{d}} \mathrm{A}=$ alluvial basin fill; $\mathrm{CLV}=$ Clear Lake Volcanics; $\mathrm{F}=$ Franciscan Complex; GV = Great Valley sequence; Sp = serpentinite; ${ }^{\mathrm{e}} \mathrm{O}_{2}+\mathrm{Ar}$. parentheses $=$ formation or unit at depth. 


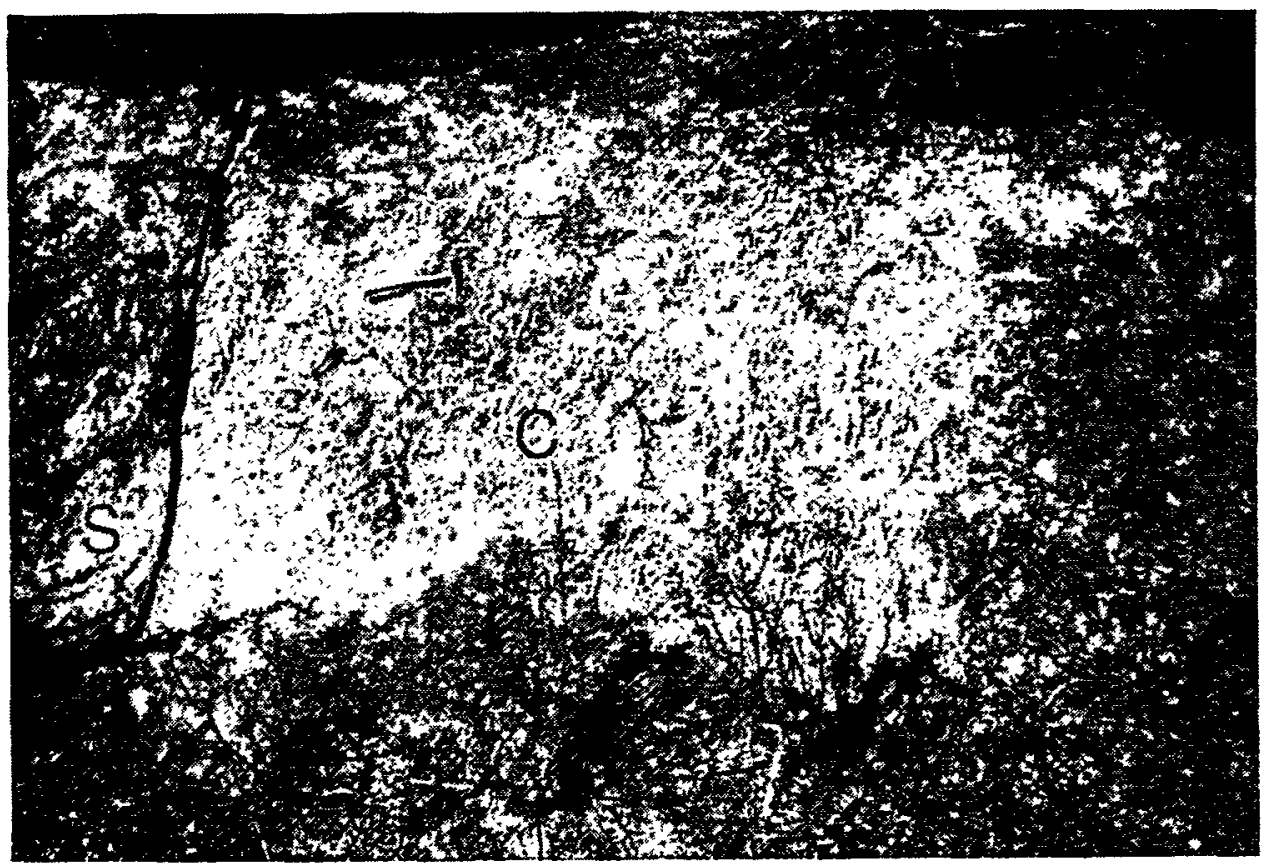

Figure 7. View west of unnamed fault (vertical black line) exposed along Walker Ridge Road. The rock hammer is shown for scale; $S=$ serpentinite and $C=$ chert.

Continue south about 13.7 miles to the junction with Highway 20. You will pass through several miles of massive serpentinite and eventually enter a zone consisting primarily of contorted shale of the FC. This stretch of road affords great views of Cortina Ridge, the Central Valley and the 0.9- to 1.6-Ma Sutter Buttes volcanic uplift to the east (left), and Indian Valley Reservoir to the west (right). A view of the abandoned Abbott mercury mine can be seen left of the junction.

STOP 1-5: Serpentine Breccia at Turkey Run Mine. Turn left on Highway 20, drive 1.0 mile, and park at the small turnout on the left side of the highway. This is an abandoned entrance to a dirt road in a narrow, north-trending gully. Walk up the old road following the water in the gully to the ruined mine structures (Figure 8). Turkey Run Mine was exploited for mercury, is part of the Sulphur Creek mining district, and was last worked in the early 1950s (Moiseyev, 1968). About 1,700 tons of mercury were produced from this district. The ore at this mine is hosted in the faulted contact of Knoxville shale and altered serpentinite. It was the opinion of Moiseyev that mercury was leached out of deep-water sedimentary rocks by saline, moderately thermal fluids, and was precipitated as $\mathrm{HgS}$ (cinnabar) along favorable structures. Although this region is also characterized by Quaternary volcanic activity, Moiseyev did not believe that the mercury originated from deep magmatic intrusions, the source of mercury in many other deposits. He did not address the possible role of $\mathrm{CO}_{2}$ as an acidifying or complexing agent in the fluid. Moiseyev's general model probably explains the origin of many mercury deposits in the Coast Ranges. 


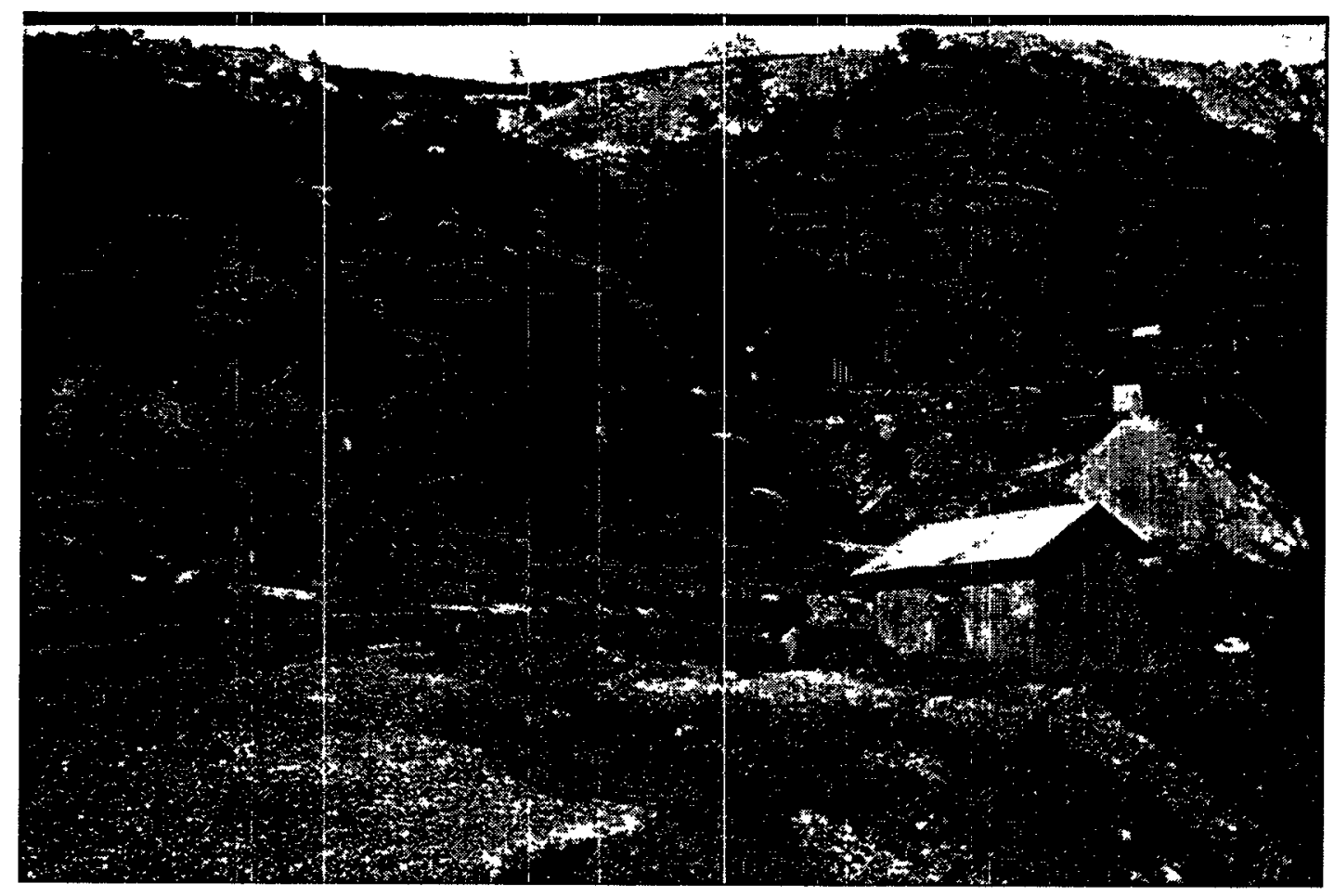

Figure 8. View looking north of abandoned structures at Turkey Run Mine. The mine dump is partially exposed to the right of the view. Turkey Run Spring issues from the collapsed adit in the grassy slope to the right of the "S."

Excellent specimens of mottled cinnabar in brecciated SC rock can be found on the mine dump. Note veining of quartz and magnesite in the host rock. Globules of petroleum, characterized by tan to black color and oily odor, were also deposited by the hydrothermal fluids (Bailey, 1959).

Turkey Run Spring issues from a collapsed mine adit at the base of a ridge in the gully west of the dump. The water has a salty bittersweet taste and is tepid (about $24^{\circ} \mathrm{C}$ ). The sulfate content is unusually high for mineral waters in this region (Table 2). The area smells weakly "organic" and of $\mathrm{H}_{2} \mathrm{~S}$, but no visible gas can be seen at the source. Filamentous bacteria grow in the outflow channel.

Turn around and head west on Highway 20 toward Clear Lake. Go 12.95 miles to the junction with Highway 53. This stretch of road passes through a pull-apart basin filled with over 1,525 m of Plio-Pleistocene sedimentary rocks of the Cache Formation. Turn left (south) on Highway 53 and go 4.5 miles to the 40th Avenue stoplight in the town of Clearlake. Turn right and go about 0.5 mile to the hotel on the left. End of Day 1. 


\section{Second Day Road Log: McLaughlin Mine Area, Faulted Serpentinites South of Clear Lake, and Clear Lake Volcanic Field}

Summary-On the second day you will first get a short tour of the McLaughlin open-pit gold mine and view the relations between faults, serpentinites, and other rock types. You then drive to two abandoned mercury mines to observe SC rocks. Next, you head for the well-preserved but abandoned resort of Howard Hot Springs to view $\mathrm{CO}_{2}$-rich fluids that issue from faulted serpentinite. Afterwards, you examine more faulted serpentinite and finish with a drive through the main Clear Lake volcanic field.

Go east 0.5 miles on 40th Avenue to Highway 53 (Figure 9). Turn right and drive 2.9 miles to Lower Lake junction. Turn left and head east on Morgan Valley Road driving first through the revived community of Lower Lake and then through rolling hills underlain by rocks of the GVS. At 4.7 miles from the Lower Lake junction, pass Sky High Ridge Road on the left. If you look to the left, you will see the large travertine terrace of Baker Soda Spring (Tables 2 and 3) and then the ruins of the Baker mercury mine, both on a fault zone in a sliver of serpentinite (Figure 3). At 13 miles from Lower Lake junction, turn right into the entrance of McLaughlin Mine to sign in and meet your leader for the tour. This section of the trip requires coordination with a geologist from the Homestake Mining Co., which you must arrange in advance. After signing in, follow the leader.

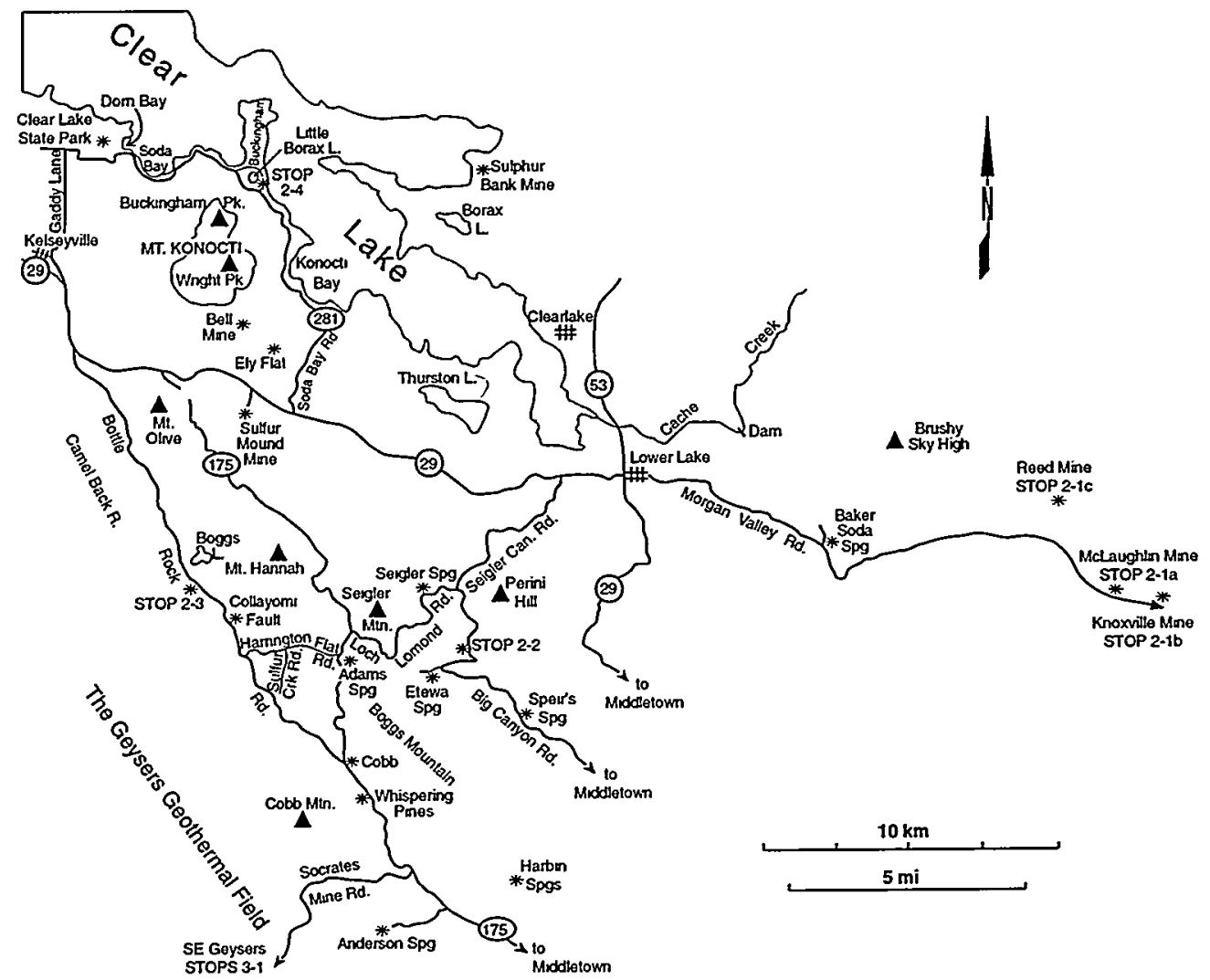

Figure 9. Route map for Days 2 and 3.

STOP 2-1a: McLaughlin Gold Mine. The following description is extracted from Lehrman (1986) and Tosdal et al. (1993). The McLaughlin gold deposit lies along the Stony Creek fault, a major structural feature that separates GVS from serpentinite melange. 
The melange contains fragments of Coast Range ophiolite and FC rocks. The GVS in the mine area consists of shale and mudstone of the Knoxville Formation, which are altered by hydrothermal activity near the fault zone. Where it is mineralized, the serpentinite is altered to silica-carbonate rock. A lava flow capping the ridge northeast of the pit has an age of 2.2 Ma. The hydrothermal alteration is dated at about 0.7 Ma. Four distinct intrusive bodies were locally emplaced along the Stony Creek fault. The largest intrusion is the Johntown neck, an andesitic vent complex. The intrusive activity is a southeastern extension of the Clear Lake volcanic field.

The Manhattan mercury deposit occupied the southern part of the most recently mined gold orebody. The orebody was discovered just beneath a siliceous sinter $\left(\mathrm{SiO}_{2}\right.$-rich hot spring deposit) and consisted of a sheeted vein $60 \mathrm{~m}$ by $60 \mathrm{~m}$ occurring over a vertical interval of $130 \mathrm{~m}$. This vein complex contained $721,000 \mathrm{oz}$ of gold, about $25 \%$ of the gold in the deposit. Numerous closely spaced veins with no intervening country rock comprise the sheeted vein. Other mineralized veins occur in the Johntown neck and the serpentinite melange. Gold often occurs in spectacular coarse-grained dendrites in these veins.

Although the veins consist primarily of quartz, chalcedony, and opal, the veins also contain calcite $\left(\mathrm{CaCO}_{3}\right)$, stibnite $\left(\mathrm{Sb}_{2} \mathrm{~S}_{3}\right)$, pyrargyrite $\left(\mathrm{Ag}_{3} \mathrm{SbS}_{3}\right)$, cinnabar, and petroleum. Mineral deposition in deeper levels occurred at $\leq 260^{\circ} \mathrm{C}$ (Sherlock et al., 1995).

This is an excellent example of an open-pit mine (Figure 10) in rocks that would be similar to those mined in a surface sequestration operation. Among many considerations, what is the cost of mining a ton of this rock? What are the environmental restrictions involved in a mine such as this? How long is the operator responsible for environmental monitoring? What economic impacts would a mine such as this have in a semiremote part of California?

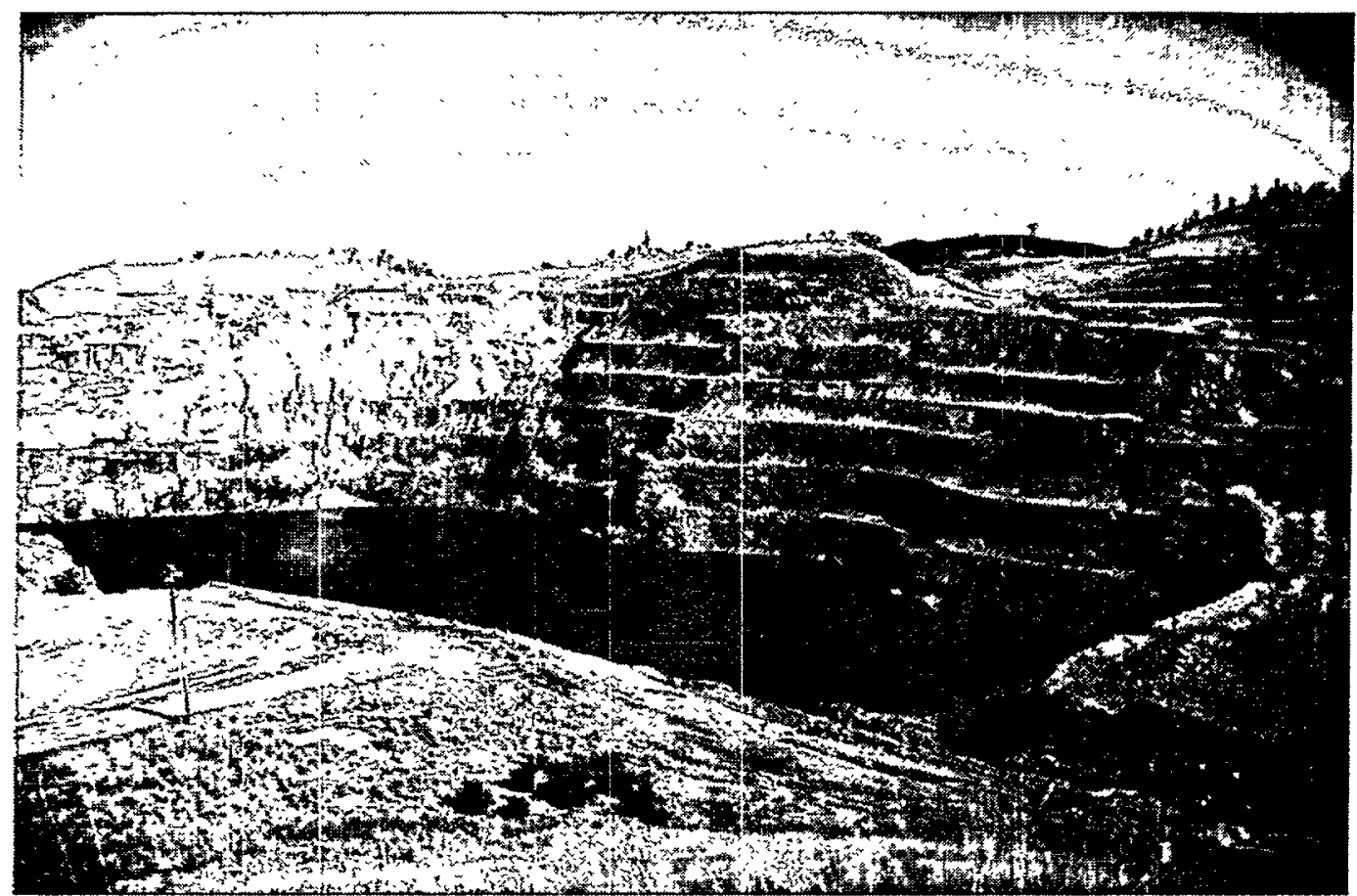

Figure 10. View northeast of McLaughlin open-pit gold mine. The pit is over $100 \mathrm{~m}$ deep. According to mine geologists, the pit will not be backfilled, and it will become a small lake. Surrounding areas will be landscaped and replanted with indigenous plants. 
STOP 2-1b: Knoxville Mine and Silica-Carbonate Rock. The following discussion is extracted from Rytuba et al. (1993). Mercury mineralization was first discovered at Knoxville in 1862; production began that same year and was continuous until about 1910 but only sporadically thereafter until 1948 . Total mercury production has been 120,850 flasks, making Knoxville the sixth largest mercury deposit in the U.S. (3.75\% of total production). The deposit is localized along the Stony Creek fault, the same feature that provides structural control for the McLaughlin gold deposit. This is an older fault between the Knoxville shale and the serpentinite.

The orebody at Knoxville is hosted by silica-carbonate altered serpentinite that forms a prominent linear knob (Figure 11). Several parallel zones of SC veins are present in the upper portions of the fault zone but these coalesce into one narrow vein at depth. SC alteration persists to a depth of at least $250 \mathrm{~m}$. Cinnabar and metacinnabar are the dominant ore minerals, but native mercury, iron sulfides, carbonates, and petroleum are also present.

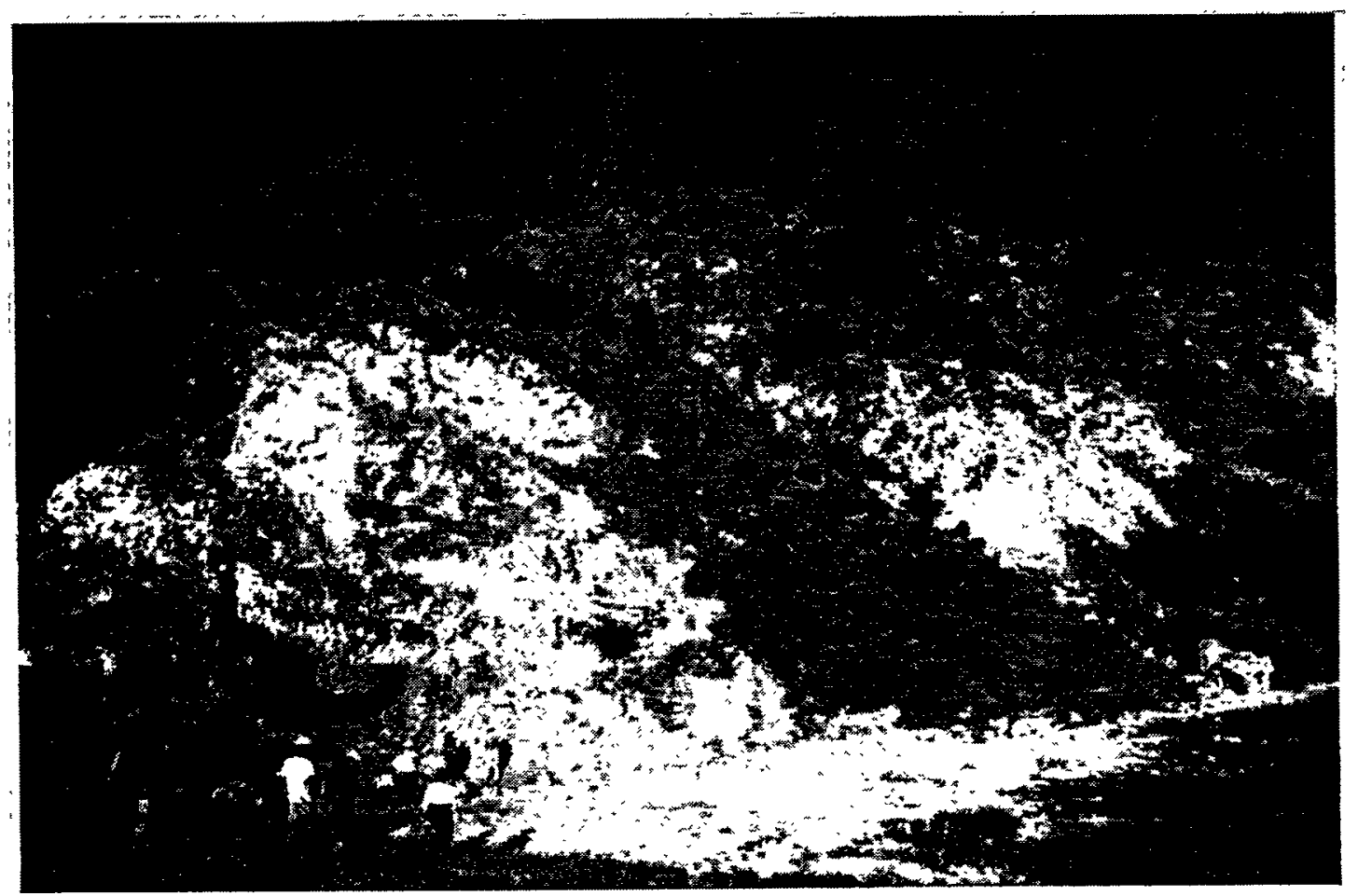

Figure 11. View north of faulted silica-carbonate rock at Knoxville mercury mine.

The SC rock exposed in the quarry face is primarily a coarse breccia of silica (quartz and some opal) with abundant coatings of iron oxides from the breakdown of iron sulfides. Faulting continued after initial hydrothermal alteration of the original serpentinite.

The area southeast of the silica-carbonate outcrop contains a marsh with springs that discharge cool, carbonated waters high in magnesium and iron (D. Enderlin, Homestake Mining Co.). The iron oxidizes to $\mathrm{Fe}(\mathrm{OH})_{3}$ and forms the bright orange-red precipitates in the mud of the marsh. The springs also discharge free gas rich in $\mathrm{CO}_{2}$.

STOP 2-1c: Reed Mine and Silica-Carbonate Rock. The Reed Mine lies on a northwest-trending fault that brings serpentinite on the southwest against the Knoxville Formation on the northeast (Averitt, 1945). The gouge zone along the fault contains fragments of FC rocks. SC rock is the host for cinnabar deposits and occurs along the 
edge of the serpentinite and in the gouge zone (Figure 12). The SC is up to $35 \mathrm{~m}$ wide and extends over a distance of at least $1.5 \mathrm{~km}$. Mineralization consists mainly of silica minerals, cinnabar, iron sulfides, calcite, magnesite, dolomite $(\mathrm{Ca}, \mathrm{Mg}) \mathrm{CO}_{3}$, and petroleum. The petroleum is green (kurdesite) on freshly broken surfaces, has a sweet organic odor, and drips from the rock. Most faulting preceded mineralization, but minor fault movements occurred after mineralization.

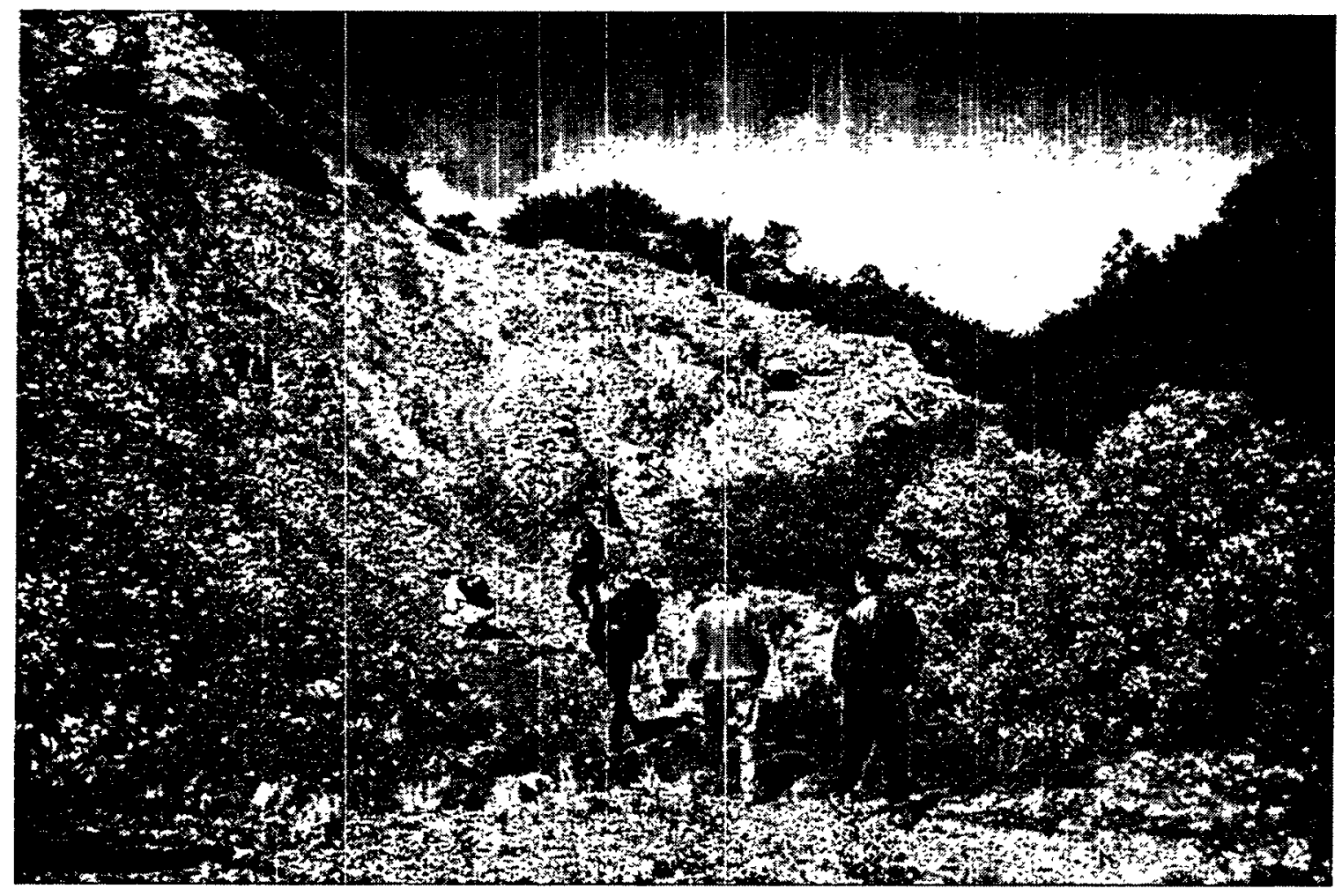

Figure 12. View north of the workings at the Reed Mine. Dean Enderlin (to right of kneeling man) examines serpentine left (west) of the iron-stained alteration zone in silica-carbonate rock.

The deposit was first exploited during 1870 to 1880 when nearly 10,000 flasks of mercury were produced. The mine was since abandoned but reopened in the early 1940 s and became the last major producer of mercury in the Knoxville district $(2,422$ flasks in 1942).

The mine workings expose faulted rocks that show rapid gradations from green, platy serpentinite to iron-stained SC rock. Hydrothermal fluids that caused alteration were probably rich in $\mathrm{CO}_{2}$ (Barnes et al., 1973) like so many present-day fluids in this region.

Return to Lower Lake junction on Morgan Valley Road (Figure 9). Continue straight ahead through the junction and stoplight on Highway 29 toward Lakeport. Drive 1.4 miles to Seigler Canyon Road. Turn left on Seigler Canyon Road. Pass Perini Hill Road on the left at 0.5 miles and continue on Seigler Canyon Road through thick, bedded sandstone of the GVS. Eventually the road passes through lava flows of the Clear Lake volcanic field (CLVF). At 3.5 miles past Perini Hill Road, turn left at the junction with Big Canyon Road. Drive 1.5 miles south on Big Canyon Road and park in the turnout on the right amidst the old resort buildings. 
STOP 2-2: Howard Hot Springs. Note: Access by special permission only. Do not trespass. Howard Hot Springs was first developed as a resort in about 1880 (Figure 13; Waring, 1915). Several improvements and renovations were made over the years, but the resort was eventually closed to the general public in the early 1970s. The buildings are in an excellent state of preservation and provide a glimpse of resort life from bygone days.

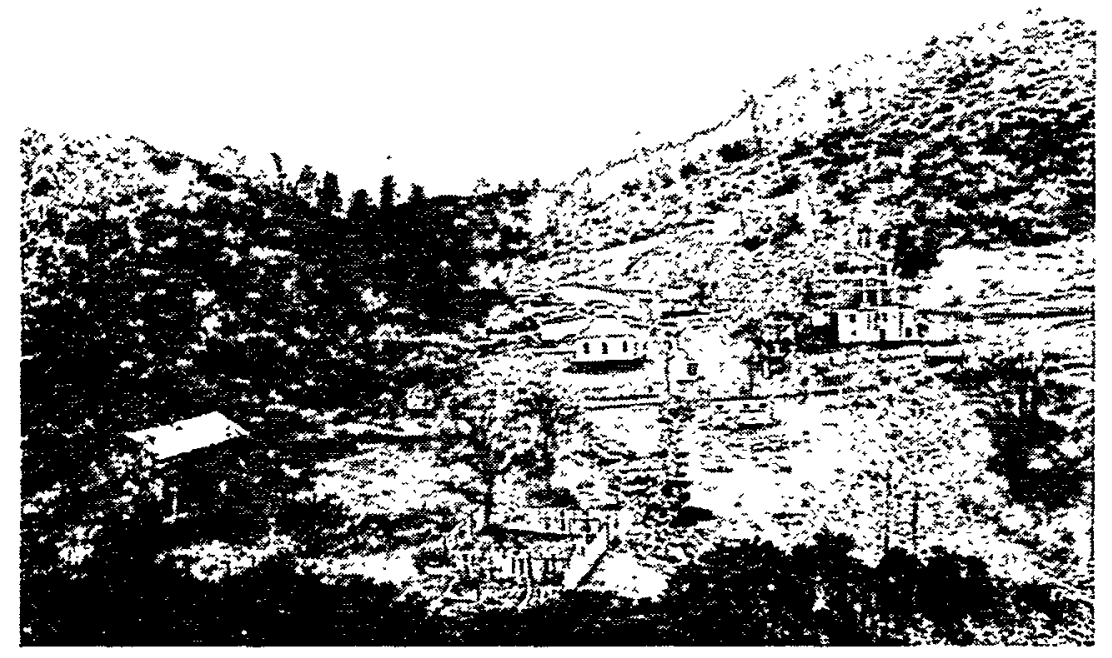

Figure 13. View northwest of Howard Hot Springs in August, 1910. Note ridge of serpentinite on the left and in the background with characteristic vegetation. Most thermal waters issue from a shear zone in serpentinite on the east side of the ridge on the left, and from a fault or fracture zone that runs up the valley. Photo is from the collection of G. A. Waring, U.S. Geological Survey.

The springs issue from faulted serpentinite and shale of the Knoxville Formation near the southern end of the Konocti Bay fault zone where this zone interconnects with the faults in Big Canyon (south of us). The serpentinite here is the southern end of a highly faulted wedge that is broader to the north. SC alteration is relatively minor at Howard Hot Springs. The hill to the north consists of massive serpentinite with some relatively unaltered peridotite, overlain by white bedded tuff $(1.0 \mathrm{Ma})$ of the CLVF. The tuff has in turn been overlain by a dacite dome and flows from Seigler Mountain ( $0.6 \mathrm{Ma}$ ).

There are roughly 40 different springs on the property but only about 10 principal ones are used for bathing and drinking. Discharge temperatures are $\leq 46^{\circ} \mathrm{C}$, and the largest spring discharges about 80,000 liters/day. Most springs precipitate some iron oxides. The waters taste mildly saline, slightly sweet, and strongly bicarbonated (Table 2). The gas (Table 3 ) is $99 \% \mathrm{CO}_{2}$.

Turn around and return 1.5 miles to the junction with Seigler Canyon Road. Turn left on Loch Lomond Road and pass Hoberg's Airport on the left, a little-used airstrip whose heyday occurred during the Big Band era of the late 1930s and early 1940s. Pass through faulted GVS sandstone and white bedded tuff of the CLVF, pulling out on the right at 0.7 mile from Seigler Canyon Road junction.

View Stop, Seigler Hot Springs Outcrop: On the right side of the road, a knob of sheared SC rock underlies a wood fence on the property of Seigler Hot Springs resort, once a thriving spa but now home to a semisecret religious cult. Hot springs here discharge at $\leq 52^{\circ} \mathrm{C}$, are $\mathrm{CO}_{2}$-rich, and are compositionally similar to those at Howard Hot Springs (Barnes et al., 1973; Tables 2 and 3). The silica-carbonate rock is primarily 
opaline but is partially iron-stained from oxidation of pyrite. Scientists have not been welcome to visit Seigler Hot Springs since about 1976.

Continue 0.3 miles to the junction with Seigler Springs Road North. Continue 3.0 miles south on Loch Lomond Road driving through pleasant forest and homes on the flank of Seigler Mountain. Turn left at the junction with Highway 175 in the resort community of Loch Lomond. Pass Loch Lomond church on the left and pass a long outcrop of tuff overlying steeply dipping beds of GVS sandstone on the right. Go 0.5 mile to the junction with Harrington Flat Road. Turn right on Harrington Flat Road and drive roughly 1.2 miles to the junction with Sulphur Creek Road. Turn left on Sulphur Creek Road and drive about 1.5 miles to the junction with Bottle Rock Road, descending a rather steep ridge of serpentine facing Kelsey Creek Valley. Turn right (northwest) on Bottle Rock Road and drive 0.3 mile, pulling out on the left at a convenient spot.

View Stop, Collayomi Fault Zone Splay: A fabulous outcrop occurs on the right side of the road showing a reverse fault in which serpentinite and sheared SC rock are thrust over Quaternary stream deposits containing clasts of CLVF and FC rocks (Figure 14). This fault splay is part of the Collayomi fault zone, another major right-lateral, strike-slip fault in the San Andreas transform zone (Goff et al., 1977; Furlong et al., 1989; Hearn et al., 1995). The Collayomi fault zone is roughly $0.25 \mathrm{~km}$ wide and is defined by linear valleys and fault contacts between various rock units. The SC alteration at this outcrop suggests that this sector of the fault was once a conduit for $\mathrm{CO}_{2}$-rich fluids during the last $1.0 \mathrm{Myr}$. A cool $\left(22^{\circ} \mathrm{C}\right.$ ) carbonated spring (Sulphur Creek Spring) discharging $\mathrm{CO}_{2}$ and $\mathrm{H}_{2} \mathrm{~S}$ gases occurs in faulted serpentinite about $0.5 \mathrm{~km}$ northeast of this outcrop (Goff and Janik, 1993).

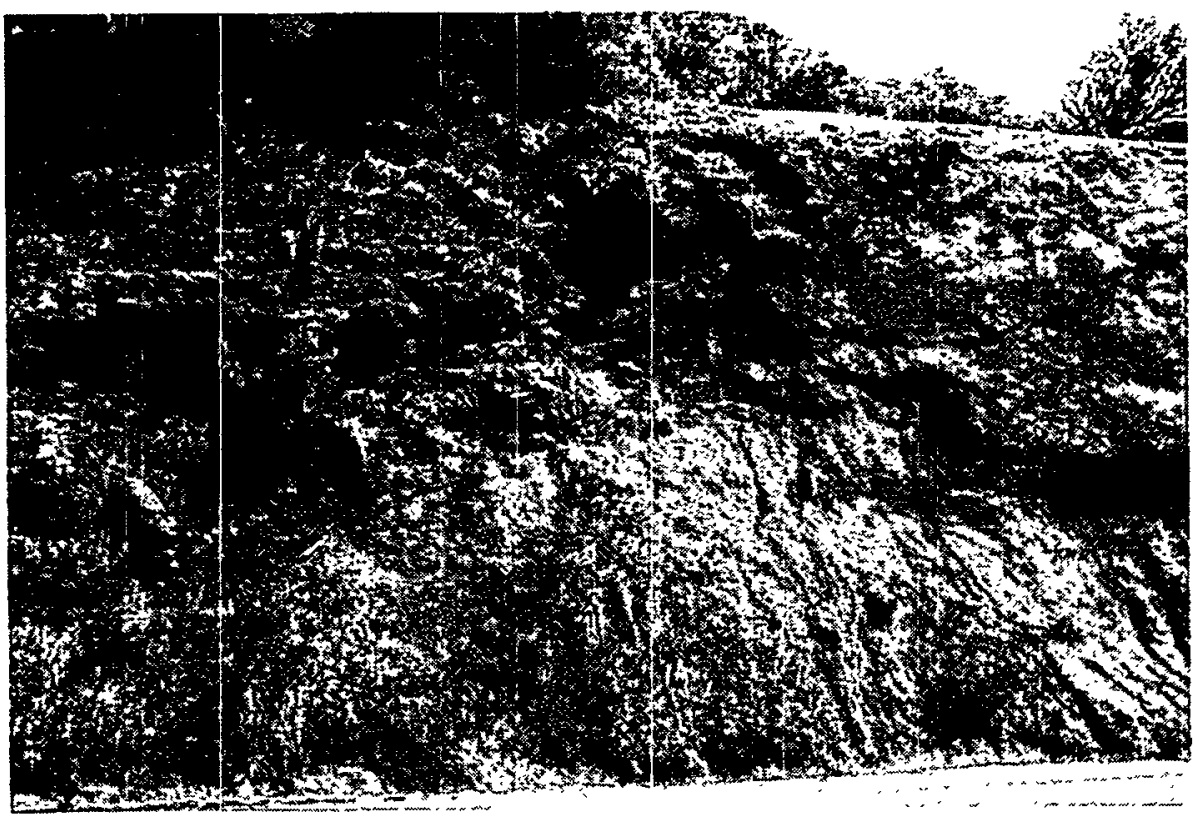

Figure 14. View northeast of thrust fault in Collayomi fault zone juxtaposing brecciated silica-carbonate rock (left, above) over poorly bedded Quaternary gravel and sand deposits. The rock hammer (lower left) occurs just below the fault plane and shows the scale. 
Continue 1.5 miles northwest on Bottle Rock Road, parking in the turnout on the left side of the road.

STOP 2-3: Serpentinite along Collayomi Fault Zone. The serpentinite at this location has the distinctive grass-poor, brush-rich vegetation with scattered gray pines so common to this rock type in the Coast Ranges. The serpentinite is a faulted slab of Coast Range ophiolite that overlies FC rocks to the southwest along the regional Coast Range Thrust. Very little serpentinite, except in smaller fault slices, is found west of here. Northeast are rocks of the CLVF. The Collayomi fault zone is more or less the boundary to The Geysers steam field (Goff et al., 1977). Some power plants with plumes of condensed steam may be seen to the west.

Although the serpentinite looks slab-like in outcrop configuration, it actually dips steeply to the northeast and becomes very thick. A geothermal exploration well (Sullivan \#1) was drilled near here to a depth of $1871 \mathrm{~m}$, completely in serpentinite. No geothermal fluids were encountered. The bottom hole temperature was $190^{\circ} \mathrm{C}$, and the bottom hole gradient was $270^{\circ} \mathrm{C} / \mathrm{km}$. No commercial geothermal wells have been drilled in or northeast of the Collayomi fault zone (Goff et al., 1977; Stimac et al., in press).

Continue northwest on Bottle Rock Road. Pass the entrance on the left at 0.4 mile to the Coldwater Creek geothermal plants (now mostly abandoned). Drive another 4.7 miles on Bottle Rock Road, passing into lava and obsidian flows (bottle rock) of CLVF and descending a long grade toward Big Valley to the junction with Highways 29 and 175. Turn left at the junction and drive 2.25 miles to the Main Street turnoff into Kelseyville. Turn right on Main Street and drive 0.45 miles into Kelseyville past the high school on the right. Turn right on State Street and drive 0.5 miles. Turn right (east) on Gaddy Lane and drive 2.1 miles to Soda Bay Road. Gaddy Lane makes a bend to the north. Mount Konocti, a large compound dacite dome of the CLVF, dominates the landscape to the east. Most of Mount Konocti was formed between 0.4 and $0.2 \mathrm{Ma}$. Large walnut orchards cover the flank of Mount Konocti, and vineyards and pear orchards fill Big Valley.

Turn right on Soda Bay Road and pass the entrance to Clear Lake State Park on the left in 1.0 mile. Continue on Soda Bay Road, driving over a low pass to view Dorn Bay on Clear Lake at 0.8 mile. The rocks here consist of thick, viscous dacite flows and flow breccias. Continue 2.9 miles on Soda Bay Road, passing Soda Bay and Horseshoe Bay on the left and reaching the junction with Little Borax Lake Road. These bays contain many $\mathrm{CO}_{2}$-rich thermal springs that are exposed during low levels of the lake (Tables 2 and 3). They appear as linear bubble trains in the water, suggesting that they are fault-controlled. Bear left on Little Borax Lake Road and drive 0.7 mile to the junction with Crystal Drive. Turn right on Crystal Drive and park on the right in or near the lot of Buckingham Country Club.

STOP 2-4: Little Borax Lake Maar and Buckingham Peak. The Clear Lake volcanic field is not well known because of lack of historic volcanic activity, but it is one of the youngest volcanic fields in the United States. Radiometric and carbon dates on over 100 units span about $2.0 \mathrm{Ma}$ to $\leq 10 \mathrm{ka}$. Rock types include basalt, andesite, dacite, and rhyolite (Stimac and Pearce, 1992). Dacite domes such as Buckingham Peak and Mount Konocti comprise the most voluminous eruptions $\left(-75 \mathrm{~km}^{3}\right.$ in the last $\left.400 \mathrm{ka}\right)$. Pyroclastic deposits are subordinate in volume (Hearn et al., 1995). Magma chambers beneath the CLVF are the heat source for The Geysers steam field and for all thermal phenomena in the region (Goff et al., 1977; Hearn et al., 1981; Stimac et al., in press). 
Little Borax Lake (LBL) is a maar volcano; an eruption of magma into or through a shallow lake or near-surface aquifer that forms a circular open crater of pyroclastic material (Figure 15). The deposits of LBL are called a tuff ring and consist of bedded lapilli and ash of basaltic composition. Famous examples include Koko crater, Hawaii, and Ubehebe Crater in Death Valley, California, but maar deposits are found in volcanic fields throughout the world. The exact age of LBL maar is unknown but is thought to be $\leq 50 \mathrm{ka}$. This date is based on ${ }^{14} \mathrm{C}$ ages of organic debris sandwiched between ash beds revealed in cores taken from adjacent Clear Lake (Sims et al, 1981). Thin maar beds are plastered on steep slopes of underlying dacite lava flows all along the shore of Clear Lake. This attests to the muddy nature of the deposits during deposition and also indicates that maar activity was common during recent geologic history.

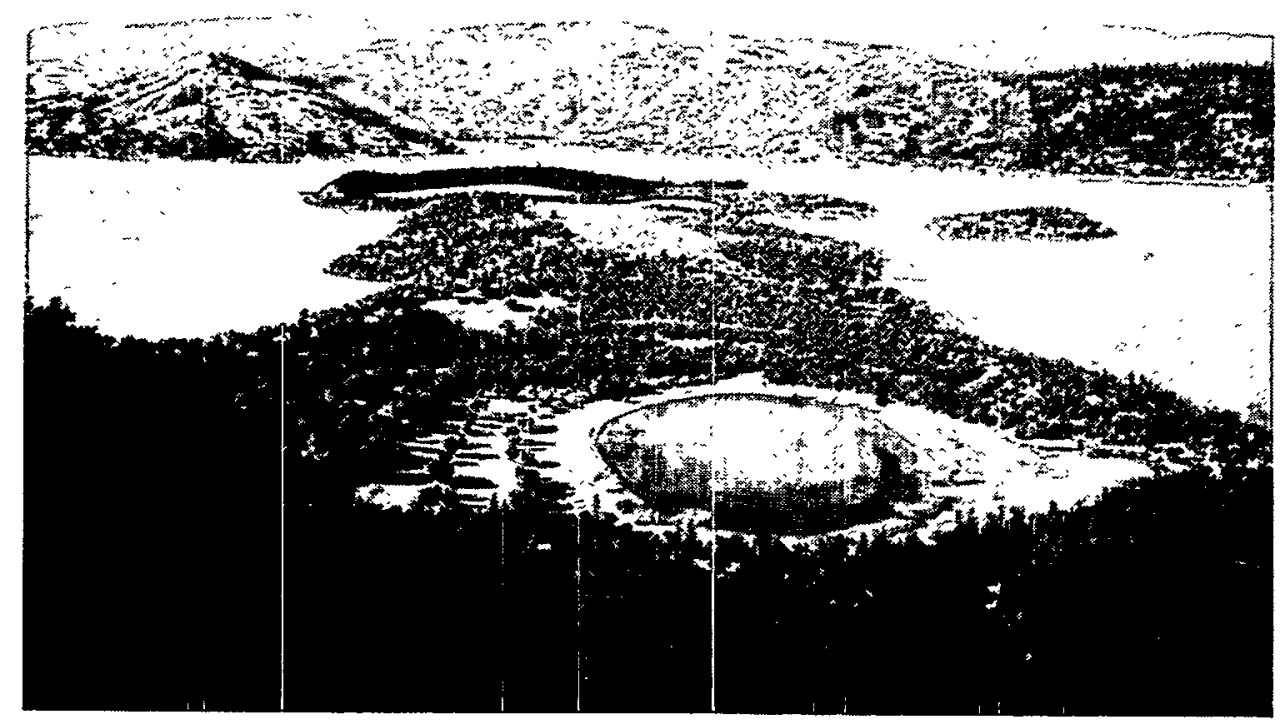

Figure 15. View north of Little Borax Lake maar and Buckingham Peninsula surrounded by Clear Lake. The peninsula is formed mostly of basaltic pyroclastic deposits of coalesced maar volcanoes. The linear trend of the peninsula is fault-controlled. Anderson Island (Kamdot) to the right of the peninsula is composed of dacite lava overlain by maar deposits. Rocks beyond the lake are mostly of the Franciscan complex. Mafic volcanism and hot spring activity in this part of Clear Lake are manifestations of relatively shallow magmatism.

There is presently no known hot spring or gas vent in LBL, but the water is abnormally rich in boron, suggesting that seepage of mineralized fluid occurs into the lake (Table 2). Many other $\mathrm{CO}_{2}$-rich mineral springs issue near the shore of Clear Lake (i.e., Big Soda and Horseshoe in Tables 2 and 3). Smaller springs in the lake appear as linear alignments of $\mathrm{CO}_{2}$ bubbles, following on-land extensions of young faults.

Leave the parking lot and continue 0.2 mile to Soda Bay Road at top of the hill. Turn left on Soda Bay Road paralleling the lakeshore. Mount Konocti is on your right. Pass Konocti Harbor Inn at 1.3 miles on left. Warm $\mathrm{CO}_{2}$-rich springs issue along the shore in this area. Continue 2.0 miles going uphill and pass the junction with Point Lakeview 
Road on the left. Continue another 1.9 miles over the crest of a hill, eventually coming to the junction with Highway 29 (if you continue straight ahead you will be on the Red Hill Road).

Turn left on Highway 29. Pass Seigler Canyon Road on the right after 6.25 miles and continue 1.35 miles further to Lower Lake junction. Turn left on Highway 53 toward the town of Clearlake and drive 2.9 miles to the 40th Avenue stoplight. Turn left and drive 0.5 mile to the hotel. End of Day 2. 


\section{Third Day Road Log: Southeast Geysers Geothermal Field and Veined Silica- Carbonate Rocks}

Summary - For the first half of the third day, you will receive a brief tour of the Southeast Geysers geothermal field and will examine serpentinite and veined SC rocks within the field. This tour will require advance coordination with a geologist from Calpine Geothermal Corporation. The second half of the day is reserved for the return trip to the Bay Area.

Go west 0.5 mile on 40th Avenue to Highway 53 (Figure 9). Turn right and drive 2.9 miles to the Lower Lake junction. Continue straight ahead on Highway 29 and drive about 15 miles to Middletown. In the approximate center of the town, turn right on Highway 175 toward the Cobb Mountain area. Drive about 5 miles to Anderson Springs Road (Tables 2 and 3) on the left, and continue 0.3 mile on Highway 175 to Socrates Mine Road. Turn left on Socrates Mine Road. Meet the leader from Calpine near the junction.

Drive roughly 3 miles into the heart of the Southeast Geysers geothermal field. Note: Access by special permission only. Do Not Trespass. The Calpine leader will determine the exact mileage and stops. Follow the leader.

STOP 3-1a: Overview of Southeast Geysers Geothermal Field. From this vantage we see several geothermal wells, steam lines, and power plants of the Southeast Geysers. To the northwest is the compound rhyolite-to-dacite dome of Cobb Mountain (1.15 to 1.0 Ma; Hearn et al., 1995) overlying FC rocks. To the northeast is the linear ridge of Boggs Mountain, a sequence of andesite flows (1.45 Ma) overlying serpentinite of the Coast Range ophiolite and GVS rocks (McLaughlin, 1981).

The Geysers geothermal field occurs in complexly deformed, texturally and compositionally variable FC rocks overlain by rhyolitic to basaltic lavas of the Quaternary CLVF (Hearn et al., 1981; McLaughlin, 1981; Hulen and Walters, 1993; Blakely and Stanley, 1995). After subduction, the original deep-water sediments were metamorphosed to blueschist- and greenschist-grade rocks. The resulting lithologies include metagraywacke and argillite as well as "greenstone" (metabasalt) and chert, locally juxtaposed structurally with serpentinite and blueschist to form chaotic melanges.

Metagraywacke and argillite make up about $90 \%$ by volume of the host rocks for The Geysers steam reservoir. These rocks occur directly above a compound magmatic intrusive complex called the "felsite" ( 1.3 to $1.0 \mathrm{Ma}$ ) that is roughly equivalent in age and compositionally similar to older Clear Lake silicic extrusive rocks. There is a strong correlation between heat flow, hydrothermal alteration, steam production, and subsurface distribution of intrusive rocks. Serpentinite occurs mostly along northwest-trending fault zones. The distribution of mercury mines and alteration zones follows the major fault trends (Figure 16). 

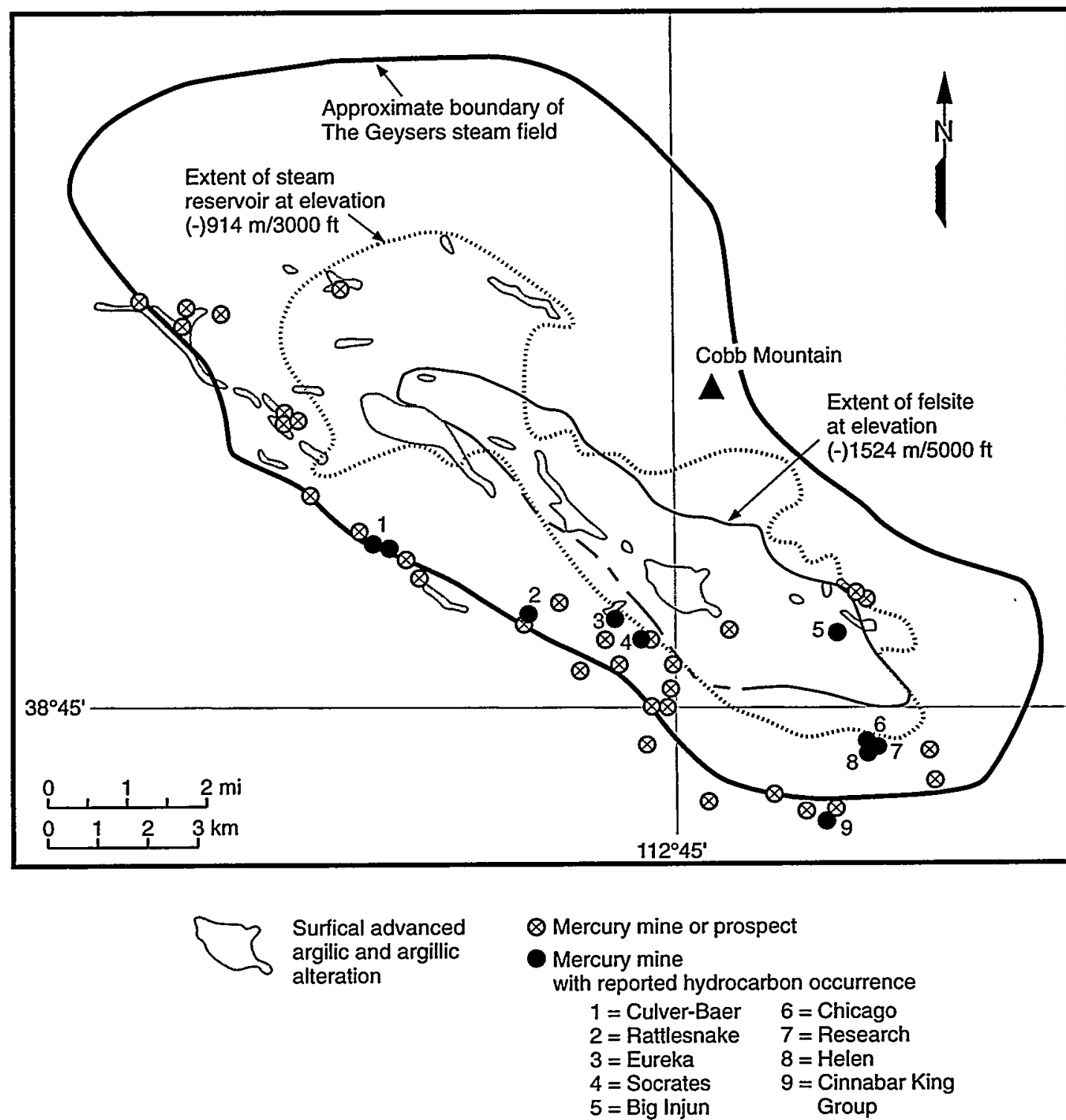

Figure 16. Map showing the spatial distribution of The Geysers steam reservoir, subjacent felsite intrusive complex, surficial alteration, and mercury deposits (from Hulen and Walters, 1993).

The hydrothermal system initially consisted of a high-temperature reservoir of liquid water $\left(\leq 350^{\circ} \mathrm{C}\right)$ that has since sealed itself and "boiled down" into a reservoir of steam (Moore and Gunderson, 1995). Early wells produced mostly dry steam at about $240^{\circ} \mathrm{C}$ and $34 \mathrm{~kg} / \mathrm{cm}^{2}$, which are approximately the temperature and pressure at the maximum enthalpy of steam (White et al., 1971). Much of the hydrothermal alteration in the field contains quartz and other vein minerals common to liquid-dominated reservoirs, but acid alteration and minerals diagnostic of vapor-dominated conditions characterize some areas. An analysis of noncondensible gas in a typical production well appears in Table 3 . Compared to other gases in the region, the steam has relatively less $\mathrm{CO}_{2}$ but much more $\mathrm{H}_{2} \mathrm{~S}$ and $\mathrm{H}_{2}$.

There are several important questions to ask with respect to the $\mathrm{CO}_{2}$ sequestration project. What is the relative age of the SC alteration of serpentinite? What effect does $\mathrm{CO}_{2}$ in the present dry steam reservoir have on serpentinite? What is the effect of serpentinite on 
geothermal activity and fluid movement? What problems does serpentinite pose for geothermal drilling activities? What are the environmental restrictions to development of geothermal resources in this complex landscape?

STOP 3-1b: Faulted and Veined Silica-Carbonate Rock near 956-1 Injection Well. The 956-1 well injects steam condensate and treated wastewater from the city of Clearlake into the geothermal reservoir. The wastewater reaches the field through a recently constructed pipeline. Injection of this water helps maintain reservoir volume and pressure.

The outcrops of serpentinite in this area are noteworthy for their structural position within the reservoir and their unstable nature (Figure 17). This serpentine is completely contained within the FC and may not be part of the Coast Range ophiolite to the east of us. Some geologists believe that the serpentine acts as a local seal or cap above steam producing horizons in underlying graywacke. The serpentine behaves plastically in the hot geothermal reservoir and has been called "a driller's nightmare."

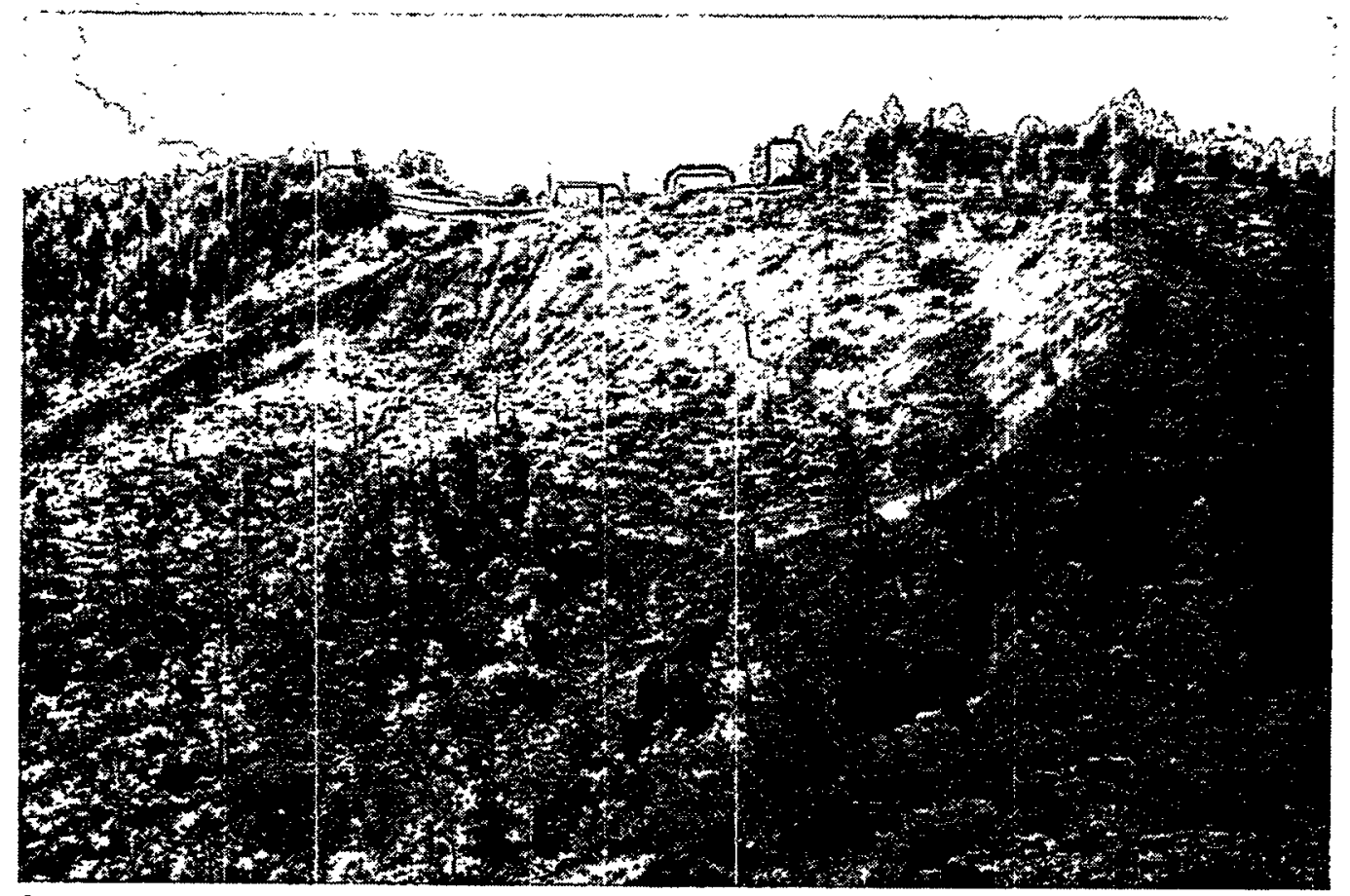

Figure 17. View west of a small landslide complex in a ridge composed of serpentinite near Power Plant 13, Southeast Geysers geothermal field. Note the typical serpentinite vegetation. Geothermal pipelines and other infrastructures are built on competent rock near the ridgecrest.

The serpentine is also interesting for its occasional chrysotile veinlets and variable alteration. Just above the well pad where we park, the road cuts across a northwesttrending lens of fairly typical green, sheared serpentinite (see cover photo). South of the well pad, this lens grades into an outcrop of highly altered and veined SC rock. The veins are composed primarily of solid to vuggy quartz with intricate cross-cutting relations. The matrix consists of carbonate-rich material that partially preserves the original textures of the serpentine. Relict patches of serpentine can be found in the SC rock. The contrast between the hard quartz veins and the soft, white-to-brown SC rock is striking (Figure 18). 


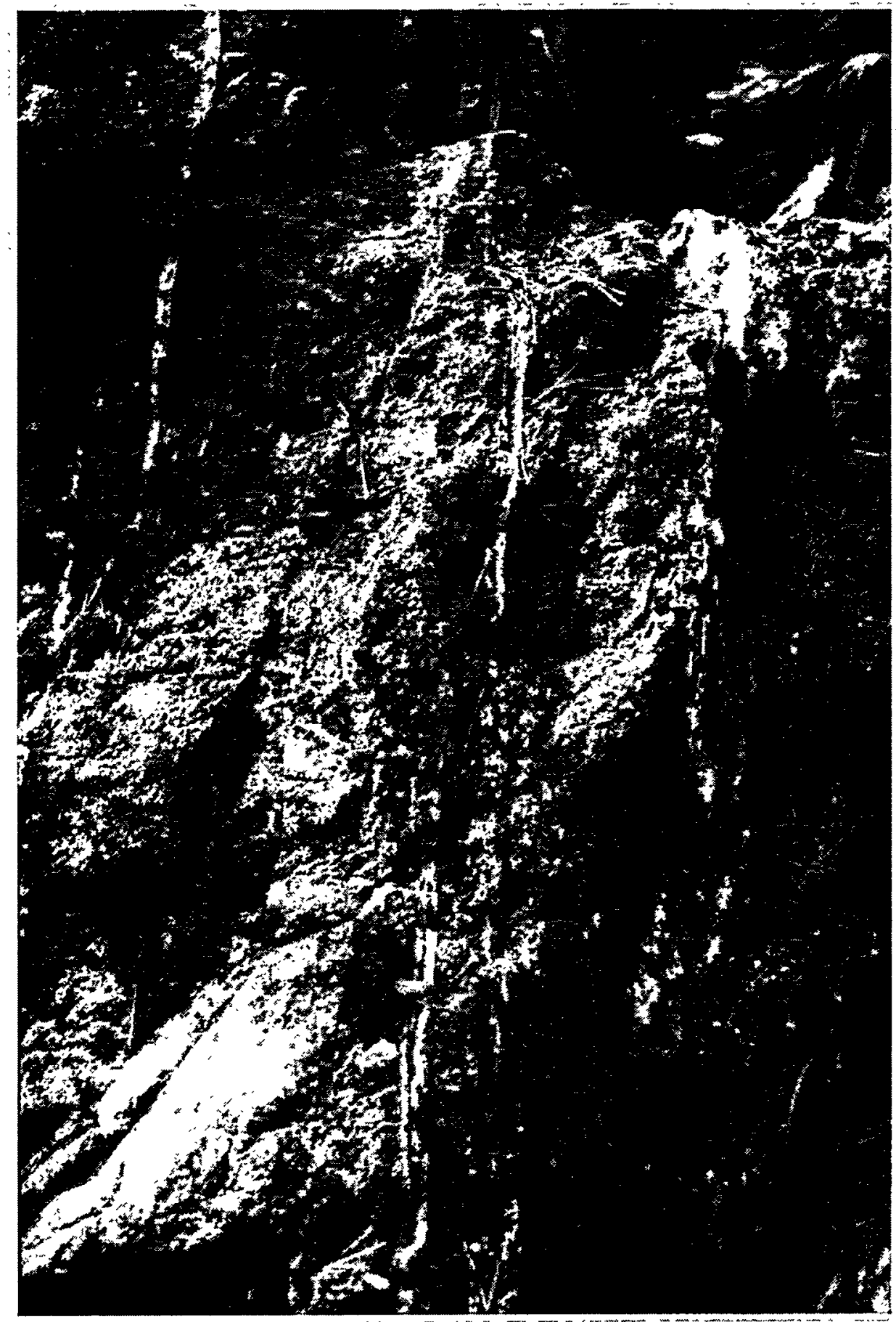

Figure 18. View of vuggy quartz veins cutting silica-carbonate rock near 956-1 injection well, Southeast Geysers.

Return to Socrates Mine Road and retrace your route back to Highway 175 . Turn right and return to Middletown. Turn right on Highway 29 and drive toward Calistoga, the Napa Valley and famous wine country, and the San Francisco Bay Area. End of Day 3 and Field Trip. 


\section{Acknowledgments}

We thank Dean Enderlin (McLaughlin Mine, Homestake Mining Company), Elio Guisti (Howard Hot Springs), and Joe Beall (Southeast Geysers, Calpine Geothermal

Corporation) for providing access to critical field trip locations and for explaining the geology of these areas. We also thank Deborah Bergfeld (LANL) for constructing Figure 3 and for reviewing the manuscript. Mable Amador (LANL) provided editorial assistance. This effort was funded by an LDRD grant (Carbon Management) from Los Alamos National Laboratory.

\section{References}

Averitt, P., 1945. Quicksilver deposits of the Knoxville district, Napa, Yolo, and Lake Counties, California: California Journal of Mines and Geology 41(2), 65-89.

Bailey, E. H., 1959. Froth veins, formed by immiscible hydrothermal fluids, in mercury deposits, California: Geological Society of America Bulletin 70, 661-663.

Bailey, E. H., Irwin, W., and Jones, D., 1964. Franciscan and related rocks and their significance in the geology of northern California: California Division of Mines and Geology, Bulletin 183, 177 pp.

Barnes, I., O'Neil, J., Rapp, J., and White, D. E., 1973. Silica-carbonate alteration of serpentine: Wall rock alteration in mercury deposits of the California Coast Ranges: Economic Geology 68, 388-398.

Barnes, I., Rapp, J., and O'Neil, J., 1972. Metamorphic assemblages and the direction of flow of metamorphic fluids in four instances of serpentinization: Contributions to Mineralogy and Petrology 35, 263-276.

Benz, H., Zandt, G., and Oppenheimer, D., 1992. Lithospheric structure of northern California determined from teleseismic images of the upper mantle: Journal of Geophysical Research 97, 4791-4807.

Bergfeld, D., Goff, F., and Janik, C. J., in press. Carbon isotope systematics and $\mathrm{CO}_{2}$ sources in The Geysers-Clear Lake region, northern California: Geothermics, 22 pp.

Blakely, R. J., and Stanley, W. D., 1995. The Geysers magma chamber, California: Constraints from gravity data, density measurements, and well information: Geothermal Resources Council Transactions 17, 227-234.

Coleman, R. G., 1977. Ophiolites: Springer-Verlag, New York, 229 pp.

Dickenson, W. R., and Seely, D. R., 1979. Structure and stratigraphy of fore-arc regions: American Association of Petroleum Geologists Bulletin 63, 2-31.

Donnelly-Nolan, J. M., Burns, M. G., Goff, F., Peters, E. K., and Thompson, J. M., 1993. The Geysers-Clear Lake area, California: Thermal waters, mineralization, volcanism, and geothermal potential: Economic Geology 88, 301-316. 
Furlong, K. P., Hugo, W., and Zandt, G., 1989. Geometry and evolution of the San Andreas fault zone in northern California: Journal of Geophysical Research 94, 3100-3110.

Goff, F., and Janik, C. J., 1993. Gas geochemistry and guide for geothermal features in the Clear Lake region, California, in (J. J. Rytuba, Ed.) Active geothermal systems and gold-mercury deposits in the Sonoma-Clear Lake volcanic fields, California: Society of Economic Geologists, Guidebook Series 16, Littleton, Colorado, pp. 207-261.

Goff, F., and Lackner, K. S., 1998. Carbon dioxide sequestering using ultramafic rocks: Environmental Geosciences 5, 89-101.

Goff, F., Adams, A., Trujillo, P., Counce, D., and Mansfield, J., 1992. Geochemistry of Thermal/Mineral Waters in the Clear Lake region, California and Implications for Hot Dry Rock Geothermal Development: Los Alamos National Laboratory report LA-12510-HDR, $23 \mathrm{pp}$.

Goff, F., Donnelly, J. M., Thompson, J. M., and Hearn, B. C., 1977. Geothermal prospecting in The Geysers-Clear Lake area, northern California: Geology 5, 509-515.

Goff, F., Guthrie, G., Counce, D., Kluk, E., Bergfeld, D., and Snow, M., 1997, Preliminary Investigations on the Carbon Dioxide Sequestering Potential of Ultramafic Rocks: Los Alamos National Laboratory report LA-13328-MS, 22 pp.

Hearn, B. C., Donnelly-Nolan, J. M., and Goff, F., 1981, The Clear Lake Volcanics: tectonic setting and magma sources, in (R. J. McLaughlin and J. M. Donnelly-Nolan, Eds.) Research in The Geysers-Clear Lake area: U.S. Geological Survey Professional Paper 1141, pp. 25-45.

Hearn, B. C., Donnelly-Nolan, J. M., and Goff, F., 1995. Geologic map and structure sections of the Clear Lake Volcanics, northern California: U.S. Geological Survey, Miscellaneous Investigations Series, Map I-2362, 1:24,000 scale, 3 sheets (color).

Hulen, J. B., and Walters, M. A., 1993. The Geysers felsite and associated geothermal systems, alteration, mineralization, and hydrocarbon occurrences, in (J. J. Rytuba, Ed.) Active geothermal systems and gold-mercury deposits in the Sonoma-Clear Lake volcanic fields, California: Society of Ecónomic Geologists, Guidebook Series 16, Littleton, Colorado, pp. 141-152.

Janik, C. J., and Goff, F., in prep. Magmatic, metamorphic, and connate fluids in The Geysers-Clear Lake region, California: Economic Geology.

Lackner, K. S., Wendt, C. H., Butt, D. P., Joyce, E. L., and Sharp, D. H., 1995. Carbon dioxide disposal in carbonate minerals: Energy 20, 1153-1170.

Lehrman, N. J., 1986. The McLaughlin mine, Napa and Yolo Counties, California, in (J. V. Tingley and H. F. Bonham, Eds.) Precious-Metal Mineralization in Hot Spring Systems, Nevada-California: Nevada Bureau of Mines and Geology, Report 41, pp. 85-89.

McLaughlin, R. J., 1981. Tectonic setting of pre-Tertiary rocks and its relation to geothermal resources in The Geysers-Clear Lake area, in (R. J. McLaughlin and J. M. 
Donnelly-Nolan, Eds.) Research in The Geysers-Clear Lake area: U.S. Geological Survey Professional Paper 1141, pp. 3-23.

McLaughlin, R. J., Ohlin, H., Thormahlen, D., Jones, D., Miller, J., and Blome, C., 1989. Geologic map and structure sections of the Little Indian Valley-Wilbur Springs geothermal area, northern Coast Ranges, California: U.S. Geological Survey, Miscellaneous Investigations Series, Map I-1706, 1:24,000 scale, 2 sheets (color).

Moiseyev, A. N., 1968. The Wilbur Springs quicksilver district (California): example of a study of hydrothermal processes combining filed geology and theoretical geochemistry: Economic Geology 63, 169-181.

Moore, J. N., and Gunderson, R. P., 1995. Fluid inclusion and isotopic systematics of an evolving magmatic-hydrothermal system: Geochimica et Cosmochimica Acta 59, 3887-3907.

Rich, E. I., 1971. Geologic map of the Wilbur Springs quadrangle, Colusa and Lake Counties, California: U.S. Geological Survey, Miscellaneous Geologic Investigations, Map I-538, 1:48,000 scale (color).

Rytuba, J. J., Enderlin, D. A., Donnelly-Nolan, J. M., and McLaughlin, R. J., 1993. Day Four. McLaughlin gold and Knoxville mercury deposits: Road Log, in (J. J. Rytuba, Ed.) Active geothermal systems and gold-mercury deposits in the Sonoma-Clear Lake volcanic fields, California: Society of Economic Geologists, Guidebook Series 16, Littleton, Colorado, pp. 350-361.

Sims, J. D., Adams, D. P., and Rymer, M. J., 1981. Stratigraphy and palynology of Clear Lake, California, in (R. J. McLaughlin and J. M. Donnelly-Nolan, Eds.) Research in The Geysers-Clear Lake area: U.S. Geological Survey Professional Paper 1141, pp. 219-230.

Sherlock, R. L., Tosdal, R. M., Lehrman, N., Graney, J., Losh, S., Jowett, E., and Kesler, S., 1995. Origin of the McLaughlin Mine sheeted vein complex: metal zoning, fluid inclusion and isotopic evidence: Economic Geology 90, 2156-2181.

Stanley, W. D., Benz, H. M., Walters, M. A., Villaseñor, A., and Rodriguez, B. D., 1998. Tectonic controls on magmatism in The Geysers-Clear Lake region: Evidence from new geophysical models: Geological Society of America Bulletin 110, 1193-1207.

Stimac, J. A., and Pearce, T. H., 1992. Textural evidence for mafic-felsic magma interaction in dacitic lavas, Clear Lake, California: American Mineralogist 77, 795-808.

Stimac, J. A., Goff, F., and Wohletz, K., in press. Thermal modeling of the Clear Lake magmatic system, California: Implications for conventional and hot dry rock geothermal development: Geothermics, 20 pp.

Tosdal, R. M., Enderlin, D. A., Nelson, G. C., and Lehrman, N. J., 1993. Overview of the McLaughlin precious metal deposit, Napa and Yolo Counties, northern California, in (J. J. Rytuba, Ed.) Active geothermal systems and gold-mercury deposits in the Sonoma-Clear Lake volcanic fields, California: Society of Economic Geologists, Guidebook Series 16, Littleton, Colorado, pp. 312-329. 
Unruh, J. R., Ramirez, V. R., Phipps, S. R., and Moores, E. M., 1991. Tectonic wedging beneath fore-arc basins: Ancient and modern examples from California and the Lesser Antilles: GSA Today 1, 1-3.

Waring, G. A., 1915. Springs of California: U.S. Geological Survey Water-Supply Paper $338,410 \mathrm{pp}$.

White, D. E., Muffler, L. J. P., and Truesdell, A. H., 1971. Vapor-dominated hydrothermal systems compared with hot-water systems: Economic Geology 66, 75-97. 